\title{
The Failure of Good Intentions: The WorldCom Fraud and the Collapse of American Telecommunications After Deregulation
}

\author{
J. Gregory Sidak ${ }^{\dagger}$
}

Seven years of attempted deregulation of telecommunications in the United States yield several lessons. First, the transactions costs of the regulatory process have grown since enactment of the Telecommunications Act of 1996. Second, if the Federal Communications Commission ("FCC") had used a consumer-welfare standard rather than a competitor-welfare standard when interpreting the Act, the agency's regulations on mandatory unbundling of local telecommunications networks would have been simpler and more socially beneficial. Third, despite its micromanagement of competition in local telecommunications, the FCC missed WorldCom's fraud and bankruptcy. WorldCom's false Internet traffic reports and accounting fraud encouraged overinvestment in long-distance capacity and Internet backbone capacity. Because Internet traffic data are proprietary and WorldCom dominated Internet backbone services, and because WorldCom was subject to regulatory oversight, it was reasonable for rival carriers to believe WorldCom's misrepresentation of Internet traffic growth. WorldCom's accounting fraud may have destroyed billions of dollars of shareholder value in other telecommunications firms. In addition, WorldCom's misconduct may have been intended to harm competition by inducing exit (or forfeiture of market share) by the efficient rivals. Chapter 11 reorganization of WorldCom would further distort competition in the long-distance and Internet backbone markets. The FCC has a unique obligation to investigate the harm that WorldCom caused the telecommunications industry. If WorldCom is unqualified to hold its FCC licenses and authorizations, that legal conclusion would promptly, and properly, propel WorldCom toward liquidation.

$\dagger$ F. K. Weyerhaeuser Fellow in Law and Economics Emeritus, American Enterprise Institute for Public Policy Research. This Article is based on my Beesley Lecture in Regulation, delivered at the Royal Society of Arts in London on October 1, 2002. I thank Colin Robinson of the Institute of Economics Affairs and Leonard Waverman of London Business School for inviting me to speak. In the months following my lecture, several telecommunications companies retained me to analyze the WorldCom fraud and bankruptcy in greater depth. They have permitted me to incorporate that additional analysis into this Article. I thank Allan T. Ingraham, Hal J. Singer, and workshop participants at Yale Law School for valuable comments and Brian Fried, Daniel Nusbaum, Brian O'Dea, and Adelene Tan for excellent research assistance. I thank Jerry Hausman for suggesting the title of this Article. The views expressed here are solely my own and not those of the American Enterprise Institute, which does not take institutional positions on specific legislative, regulatory, adjudicatory, or executive matters. 


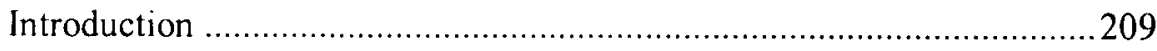

I. The Administrative Cost of Deregulation......................................211

II. Mandatory Unbundling Under the Competitor-Welfare Standard

III. The Collateral Damage to the Telecommunications Industry from WorldCom's Fraud and False Statements

A. False Internet Traffic Reports That Encouraged Overinvestment in Long-Distance Capacity

B. WorldCom's Accounting Fraud May Have Destroyed Billions of Dollars of Shareholder Value in Other Telecommunications Firms

C. Incorrect Information Supplied to State and Federal Governments That Was Essential to Formulating Telecommunications Policies

D. Can Federal Courts, Regulators, Congress, and Cabinet Departments Trust WorldCom's Filings?

IV. Were WorldCom's Fraud and Bankruptcy Intended To Achieve an Anticompetitive Purpose?

A. Repeated Misrepresentation of Financial Performance.

B. Fraudulent or False Statements as a Means To Raise Rivals' Costs

C. Reduced Cost of Capital and Facilitation of Acquisitions.

D. During the Prebankruptcy Period, WorldCom's Fraud Facilitated a Business Strategy That May Have Been Designed To Harm Rival Providers of Internet Backbone or Long-Distance Services.

1. Because WorldCom's Real Costs Were Unknown, Its Pricing of Internet Backbone Services Bore No Relation to Cost and Thus Served To Distort Competition

2. Recoupment of Losses Was Unnecessary as a Condition for Plausible Predation by WorldCom Because Its Management Had Other Ways To Profit Personally 
3. The Coordinated Actions of WorldCom's

Management, Its Investment Bankers, and Its

Auditors May Have Injured Competition in

the Telecommunications Industry

V. The FCC's Unique Obligation To Investigate WorldCom's

Harm to the Telecommunications Industry

A. After Chapter 11 Reorganization, WorldCom

Could Underprice Efficient Rivals.

B. Chapter 11 Reorganization as State Aid in

Violation of Article 87 of the European

Community Treaty.

C. The Differing Responsibilities of the Securities

and Exchange Commission, the Bankruptcy

Court, and the FCC

VI. Revocation and Liquidation as the Proper Result

A. The Negligible Social Cost from WorldCom's

Demise as a Going Concern

B. Other Carriers Could Competitively Supply

WorldCom's Customers

VII. Lessons Learned

Introduction

The United States has spent seven years trying to deregulate telecommunications. We are not in the "transition" any longer. It is time to take stock. In this Article, I address three topics. The first, addressed in Part $I$, is the administrative cost of deregulation under the Telecommunications Act of 1996.' Next, I examine in Part II the consequences of the Federal Communications Commission's ("FCC's") use of a competitor-welfare standard when formulating its policies for local competition, rather than a consumer-welfare standard.

Beginning in Part III, I address at greater length my third topic. I offer an early assessment of the harm to the telecommunications industry from WorldCom's fraud and bankruptcy. I explain how WorldCom's misconduct caused collateral damage to other telecommunications firms, government, workers, and the capital markets. WorldCom's false Internet traffic reports and accounting fraud encouraged overinvestment in long-

1 Telecommunications Act of 1996, Pub. L. No. 104-104, 110 Stat. 56 (codified as amended in scattered sections of 47 U.S.C.). 
distance capacity and Internet backbone capacity. Because Internet traffic data are proprietary and WorldCom dominated Internet backbone services, and because WorldCom was subject to regulatory oversight, it was reasonable for rival carriers to believe WorldCom's misrepresentation of Internet traffic growth. WorldCom's accounting fraud may have destroyed billions of dollars of shareholder value in other telecommunications firms and eroded investor confidence in equity markets. Using event-study analysis, I estimate the harm to rival carriers and telecommunications equipment manufacturers resulting from WorldCom's restatement of earnings. WorldCom's false or fraudulent statements also supplied state and federal governments with incorrect information essential to the formulation of telecommunication policy. State and federal governments, courts, and regulatory commissions would thus be justified in applying extreme skepticism to future representations made by WorldCom.

Part IV explains how WorldCom's fraud and bankruptcy may have been intended to harm competition, and in the future may do so, by inducing exit (or forfeiture of market share) by the company's rivals. WorldCom repeatedly deceived investors, competitors, and regulators with false statements about its Internet traffic projections and financial performance. At a minimum, WorldCom's fraudulent or false statements may have raised rivals' costs by inducing inefficient investment in capacity or inefficient expenditures for customer acquisition and may have artificially reduced WorldCom's cost of capital and thus facilitated its long string of acquisitions.

During the pre-bankruptcy period, WorldCom's business strategy may have been designed to harm rival providers of Internet backbone or long-distance services. Because WorldCom's real costs were unknown, its pricing of Internet backbone services bore no relation to cost. Recoupment of losses was unnecessary as a condition for plausible predation by WorldCom because its management had other ways to profit personally. The coordinated actions of WorldCom's management, its investment bankers, and its auditors may have injured competition in the telecommunications industry. Part V argues that the FCC has a unique obligation-distinct from the mandate of the bankruptcy court or the Securities and Exchange Commission-to investigate the effect of WorldCom's misconduct on the telecommunications industry.

For WorldCom, Chapter 11 bankruptcy can be a means to distort competition in the long-distance and Internet backbone markets. Because Chapter 11 bankruptcy is not designed to eradicate anticompetitive business models or to establish policy for the telecommunications infrastructure, the FCC is uniquely empowered to defend the competitive 
process. After Chapter 11 reorganization, WorldCom's freedom from debt would enable the firm to underprice rivals that are as, or more, efficient than WorldCom. Economic efficiency would suffer because consumers would pay less than the true social cost required to supply the services offered by WorldCom. Moreover, the competitive advantage conferred upon WorldCom by the U.S. bankruptcy court's elimination of WorldCom's debt (in whole or in part) could constitute state aid in violation of Article 87 of the European Community Treaty.

In Part VI, I argue that WorldCom's exit from the market would not carry significant social costs. WorldCom's value as a going concern is dubious, and other carriers could readily absorb WorldCom's Internet and long-distance customers. The FCC should investigate the ramifications of WorldCom's fraud for telecommunications policy. The outcome of that investigation may include the finding that WorldCom is unqualified to hold its FCC licenses and authorizations. That legal conclusion would promptly, and properly, propel WorldCom toward liquidation.

\section{The Administrative Cost of Deregulation}

My first point is a simple one: deregulation has actually increased regulation. That is not a reason to reject deregulation, but it may be a useful indicator of whether we are on the right trajectory for true deregulation. Consider first the growth of regulatory inputs.

Figure 1. FCC Appropriations in Constant Dollars

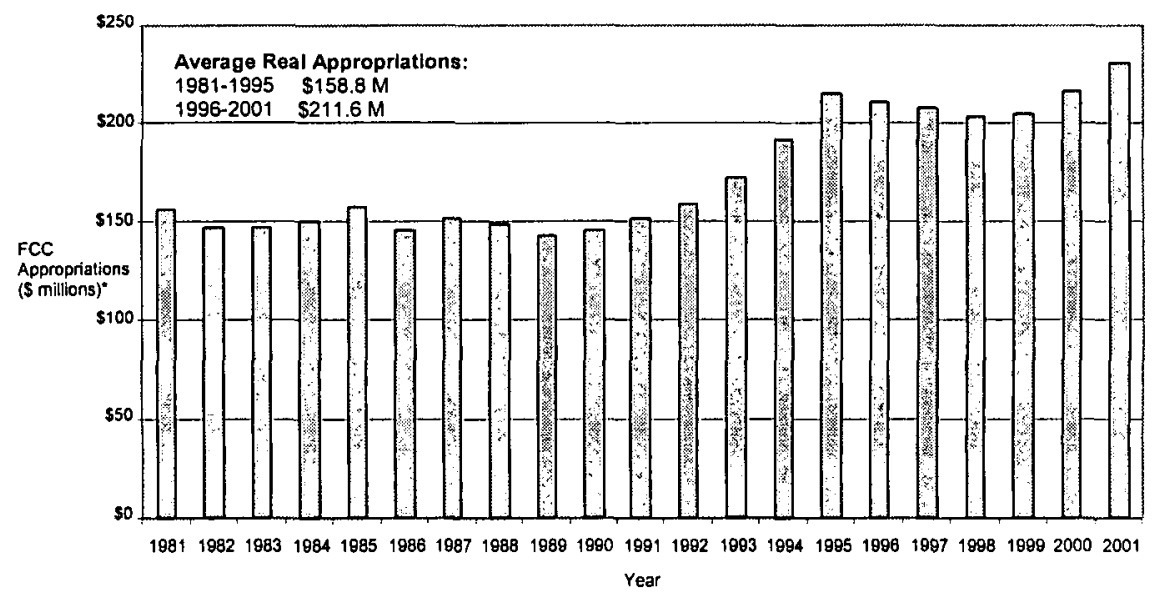

* Adjusted for inflation using the CPI-U, in 2001 dollars.

Source: 1997 FCC Record, Congressional Appropriations filings 1999-2000. 
Figure 1 shows the FCC's annual budget in inflation-adjusted dollars. Real expenditures quickly rose by about one-third after enactment of the Telecommunications Act of 1996 , from $\$ 158.8$ million to $\$ 211.6$ million, and they have stayed at that higher level. The increase is thirty-seven percent if one includes 1995 in the post-deregulation period-perhaps on the rationale that the FCC both saw new legislation coming and sought to get an early jump on some of the expected regulatory detail. What happened to regulatory output? The FCC, of course, produces many regulatory products. Some, such as inaction, are particularly difficult to quantify. But a simple, albeit imperfect, measure of output is the number of pages per year of the FCC Record, the official compendium of all FCC decisions, proposed rulemakings, adjudications, and the like. As Figure 2 shows, the number of pages per year nearly tripled in the post-1996 period. During that period, the FCC Record averaged 23,838 pages per year.

So, at a very crude level of analysis, it would appear that deregulation permanently increased the inputs and outputs of the FCC. Indeed, on the back of the envelope, it appears that a one percent increase in real expenditures for the FCC would produce about a nine percent increase in output.

Figure 2. Number of Pages of Annual FCC Record

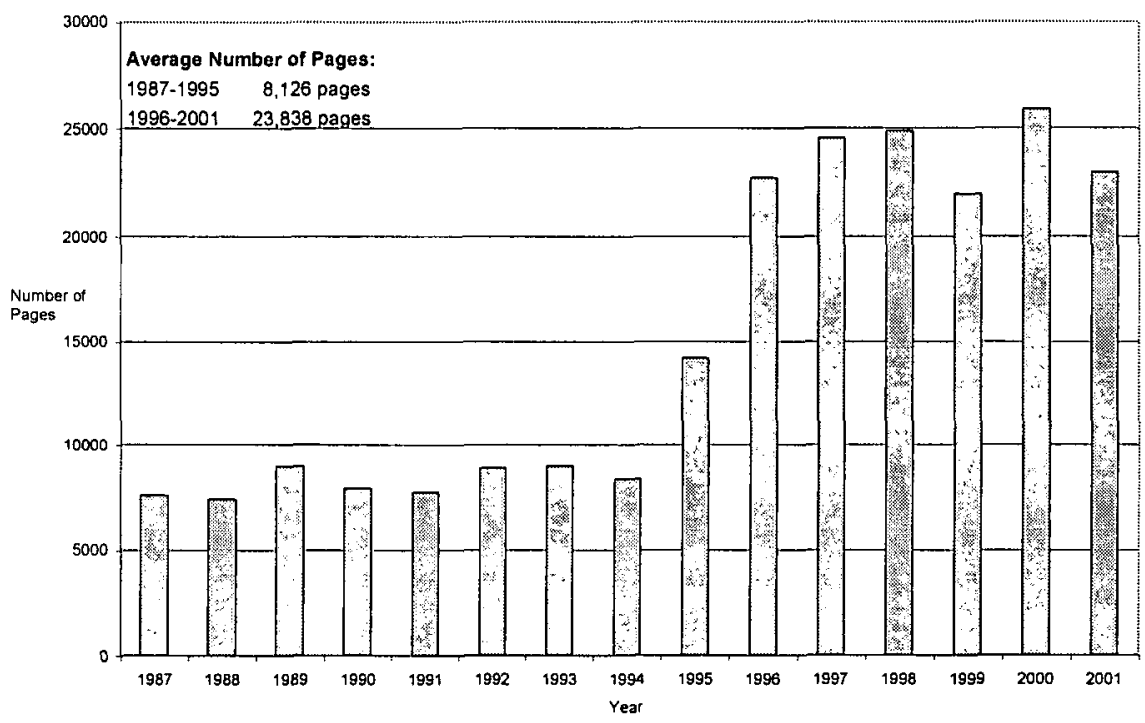

Note: The first year of the FCC Record's publication, 1986, was excluded duc to its small value $(1,368$ pages). 
How did the near tripling of the FCC's output in the post-1996 period affect the transactions costs that private firms incurred in connection with telecommunications deregulation? This question is hard to answer because the relevant data are by definition private rather than public. One anecdotal measure that is publicly available is the number of lawyers who belong to the Federal Communications Bar Association. As Figure 3 shows, this measure of the number of telecommunications lawyers grew seventy-three percent between December 1994 and December 1998. If one assumes (very conservatively) that the average income of an American telecommunications lawyer is $\$ 100,000$, then the current membership of the FCBA represents an annual expenditure on legal services of at least $\$ 340$ million.

\section{Figure 3. Growth in the Number of Telecommunications Lawyers}

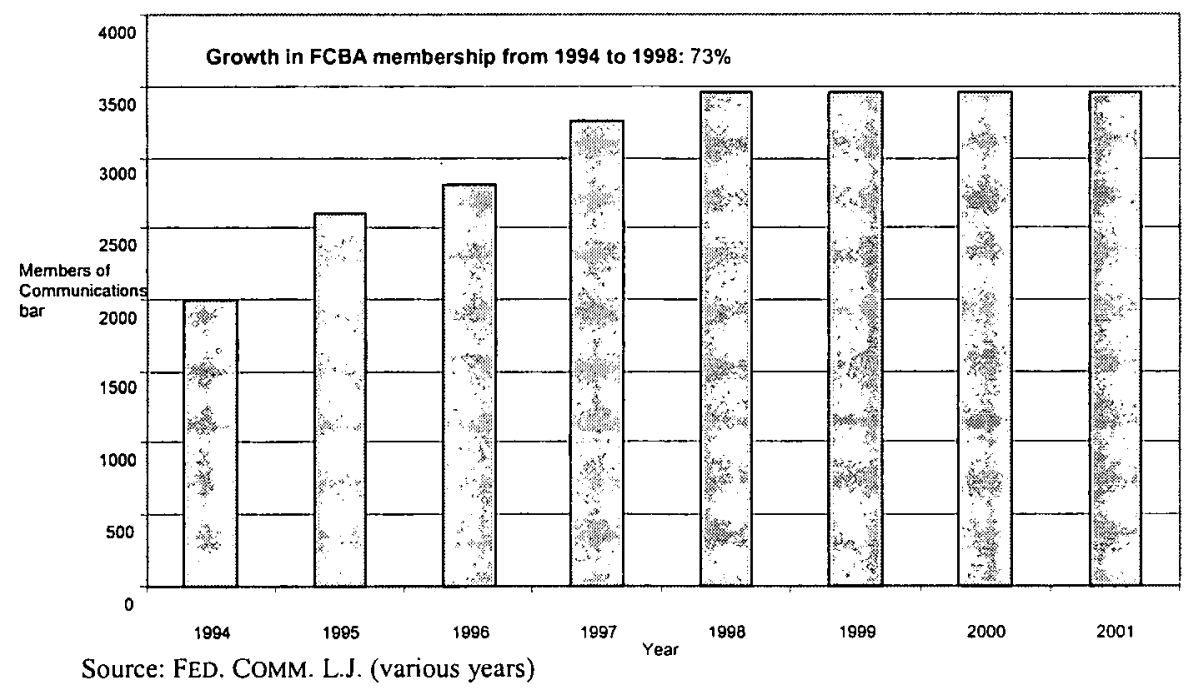

Of course, some of these telecommunications lawyers may have been laid off by now, and others may have redeployed their talents in more promising specialties - such as bankruptcy, securities litigation, and whitecollar criminal defense. But the raw data do suggest that the stock of telecommunications lawyers experienced a substantial and enduring shift upward after 1996 that tracked the increase in the FCC's real budget and the increase in its annual output as measured by the size of the FCC Record.

I have analyzed the growth in the FCC's inputs and outputs, as well as in its attorney constituency, as proxies for transaction costs. One might object that my time horizon coincided with dramatic growth in the 
telecommunications industry, and that these data might look quite different if one considered instead a measure of transactions costs per revenue dollar (or transactions costs per bit of data transmitted). I have not attempted such a calculation in the belief that it is reasonable to expect the transactions costs of telecommunications regulation to exhibit some increasing returns to scale. One would not expect the costs of regulatory compliance and strategy to be twice as high for a carrier with twice the revenues of another.

Regardless of whether one considers particular FCC policies to be good or bad, there can be no dispute that the public and private transactions costs of implementing the Telecommunications Act of 1996 have been significant.

\section{Mandatory Unbundling Under the Competitor-Welfare Standard}

What about the substance of deregulation? The centerpiece of the Telecommunications Act of 1996 was the opening of the local network. My second major point is this: Following a consumer-welfare model would have made unbundling policy simpler and more socially beneficial. Unbundling means that the owner of a network will offer competitors the use of pieces of the network on a disaggregated, wholesale basis. ${ }^{2}$ The principal policy questions that arise under unbundling are "What shall be unbundled?" and "How shall the unbundled network element be priced for sale to competitors?" Through its mandatory unbundling policies, the FCC affirmatively promoted preferred forms of market entry. Those modes of entry-and the business models predicated upon them-might have been immediately rejected in a truly deregulated marketplace rather than one that was subject to managed competition. It would not be credible to lay all the blame at Congress's feet by saying that the Telecommunications Act of 1996 compelled the FCC to follow an unbundling rule that ensured perverse economic consequences. Writing in his memoir in 2000, former FCC Chairman Reed Hundt said the following about the congressional compromises made to pass the Telecommunications Act of 1996:

2 Unbundling is the shorthand used to describe a method of entry into local telephony that relies on "the leasing of unbundled network elements, [which are] the building blocks of the local network," including loops and switches. Jerry $A$. Hausman \& J. Gregory Sidak, A Consumer-Welfare Approach to the Mandatory Unbundling of Telecommunications Networks, 109 YALE L.J. 417, 432 (1999). "The entrant can then build its own network à la carte by buying some inputs from the ILEC and procuring other inputs from rivals already in the market (such as local transport services provided by competitive access providers) or directly from equipment vendors (such as manufacturers of switches)," id. at $432-33$. 
The . . compromises had produced a mountain of ambiguity that was generally tilted toward the local phone companies' advantage. But under principles of statutory construction, we had broad . . . discretion in writing the implementing regulations. Indeed, like the modern engineers trying to straighten the Leaning Tower of Pisa, we could aspire to provide the new entrants to the local telephone markets a fairer chance to compete than they might find in any explicit provision of the law. ${ }^{3}$

Mr. Hundt's stratagem worked. By a 7-1 margin in Verizon Communications Inc. v. FCC, ${ }^{4}$ the FCC's lawyers successfully convinced the Supreme Court in 2002 of the reasonableness of the agency's pricing rules for unbundled network elements ("UNEs").

Those rules are predicated on the novel concept of total element longrun incremental cost ("TELRIC"). ${ }^{5}$ The TELRIC concept was so nuanced that the FCC devoted more than 600 pages to explaining it. Even if the FCC's TELRIC pricing model was not the best possible interpretation on economic grounds, it was deemed by the Court to deserve deference on review under the Chevron doctrine. ${ }^{6}$ How much leeway did that imply? A great deal, for Justice David Souter wrote for the Court that the Telecommunications Act of 1996 created a "novel ratesetting designed to give aspiring competitors every possible incentive to enter local retail telephone markets, short of confiscating the incumbents' property.",

And what if those incentives led to a trillion dollars or more of wasted investment? That was not the Supreme Court's problem. With the exception of Justice Stephen Breyer, the Court would defer to any method, even one never contemplated by Congress in the Telecommunications Act of 1996, that the FCC might devise for pricing UNEs-that is, as long as the Court did not think that the method constituted a government taking of private property. And the Court signaled in the same opinion that it had no appetite for deciding that constitutional question anytime in the foreseeable future. ${ }^{8}$

The Court confirmed what the FCC's leadership had believed since 1996: That the agency had the wisdom to devise, and the authority to

3 ReEd E. HUNdT, You SAY You Want a Revolution: A STUDY of INFORMation AGE POLITICS 154 (2000).

4535 U.S. 467 (2002).

5 Implementation of the Local Competition Provisions in the Telecommunications Act of 1996, First Report and Order, 11 F.C.C.R. 15,499 (1996), vacated in part lowa Utils. Bd. v. FCC, 120 F.3d 753 (8th Cir. 1997), rev'd in part and aff'd in part sub nom. AT\&T Corp. v. lowa Utils. Bd., 525 U.S. $366(1999)$.

6 See Chevron U.S.A. v. Natural Res. Def. Council, 467 U.S. 837, 842-45 (1984).

7 Verizon, 535 U.S. at 489.

8 Id. at $523-28$. 
impose, the means to promote competition in local telephony. But those same officials and their successors were slow to acknowledge that the FCC correspondingly possessed the power to distort competition and investment in the telecommunications industry.

On the question of wasted investment, there is a puzzle. There currently exists excess capacity in the telecommunications industry despite FCC policies that created an incentive for underinvestment by both incumbent local exchange carriers ("ILECs") and competitive local exchange carriers ("CLECs"). ${ }^{9}$ The answer to this puzzle lies in the data. Eventually, research by empirical economists may give us a definitive autopsy. It will be necessary to examine the level of investment in local network facilities (including cable television systems and wireless systems) versus the level of investment in Internet backbone facilities, undersea cables, and other long-haul fiber-optic networks. For some investments, unrealistic predictions of demand may have more explanatory power than regulatory distortions.

A powerful factor contributing to excess capacity in long-distance telecommunications was the unexpected degree of improvement in dense wave division multiplexing. At first, a given strand of fiber was split into two channels. The technology rapidly advanced to where a given strand of fiber now has over 100 channels, with the possibility of over 1000 channels in the future. Thus, as companies installed new long-distance networks, technology improved so dramatically that capacity outpaced growth in demand, even with the Internet's rapid growth. The connection between this fact and the WorldCom bankruptcy will be apparent later in this Article.

It bears emphasis, however, that this excess capacity exists at the long-distance level, which is virtually unregulated in the United States. At the local level, relatively little new facilities investment by CLECs took place. Indeed, when Rhythms and Northpoint (the second and third largest CLECs offering DSL service) went bankrupt, their networks sold for under $\$ 50$ million each. Similarly, Global Crossing's worldwide fiber optic network, which consumed $\$ 15$ billion in financing to construct in the late 1990 s, was implicitly valued in March 2003 at only $\$ 406.5$ million. ${ }^{10}$

9 These policies are principally the FCC's 1996 rules concerning the mandatory unbundling of elements of the ILEC's local access network at regulated prices based on regulators' estimates of the ILEC'S TELRIC for the network elcment in question.

10 In March 2003, Hutchison Whampoa and Singapore Technologies Telemedia had an outstanding offer to buy $61.5 \%$ of Global Crossing for $\$ 250$ million and take the cartier out of bankruptcy. See Simon Romero, Hong Kong Company May Alter Deal To Buy Global Crossing, N.Y. TIMES, Mar. 1, 2003, at C1. This price implies a total valuation of $\$ 406.5$ ( $\$ 250$ million divided by $0.615)$. 
Thus, we observed overinvestment in long-distance networks with no regulation, and underinvestment in regulated local networks, where the FCC (and state regulators) set prices for unbundled elements and wholesale services.

For the sake of argument, suppose that those policies were lawful but foolish. What should the FCC have done? Under Chairman Michael Powell's leadership, the FCC in 2002 undertook a "Triennial Review" of its policies on mandatory unbundling of local exchange networks. At that time, the agency continued to embrace the proposition that, in its words, "access to UNEs would lead to initial acceleration of alternative facilities build-out because acquisition of sufficient customers and necessary market information would justify new construction." hypothesis. After seven years of implementing the Telecommunications Act of 1996, does empirical evidence support it? What would the FCC have to find empirically to continue to make this hypothesis the basis for its UNE rules? Empirical research by Robert Crandall of the Brookings Institution ${ }^{12}$ suggests that CLECs that built their own facilities were more likely to produce what the FCC calls "sustainable competition." ${ }^{\text {"I }}$ In New York and Texas, for example, where CLEC market share is higher than elsewhere, is there any empirical evidence that there was a greater rate of reliance on UNEs by CLECs? Answers to such questions are essential to knowing whether, as the FCC assumes, mandatory unbundling at regulated TELRIC-based prices achieves its intended purpose.

And what exactly is that purpose? Section 251(d)(2) of the Telecommunications Act requires an incumbent local exchange carrier to unbundle at a regulated price any network element which, if not offered on an unbundled basis at the regulated price, would "impair" the CLEC's ability to compete. ${ }^{14}$ The meaning of "impairment" is critical. Not surprisingly, the definition was litigated in the Supreme Court after the FCC essentially said that any UNE that can be unbundled must be unbundled. The Supreme Court concluded that such a definition had no limiting principle, and it therefore remanded the rulemaking to the $\mathrm{FCC} .{ }^{15}$

11 In re Review of the Section 251 Unbundling Obligations of Incumbent Local Exchange Carriers Implementation of the Local Competition Provisions of the Telecommunications Act of 1996 Deployment of Wireline Services Offering Advanced Telecommunications Capability, Notice of Proposed Rulemaking, CC Dkt. Nos. 01-338, 96-98, 98-147, ๆ 23 n.69 (2001) [hereinafter UNE Triennial Review NPRM].

12 See Robert W. Crandall, an assessment of the Competitive local Exchange Carriers Five Years After the Passage of the TelecommuniCations ACT (2002), available al http://www.criterioneconomics.com/documents/Crandall\%20CLEC.pdf.

13 UNE Triennial Review NPRM, supra note 11, \25.

1447 U.S.C. $\$ 251$ (d)(2) (2000).

15 AT\&T Corp, v. Iowa Utils. Bd., 525 U.S. 360 (1999). 
The FCC then decided to use the phrase "materially diminishes" to limit the scope of the statutory phrase "impairs."

In May 2002, in U.S. Telecom Association v. FCC, the FCC's impairment rule was again struck down on judicial review, this time by the U.S. Court of Appeals for the District of Columbia Circuit in an opinion by Judge Stephen F. Williams. ${ }^{17}$ At that time, the FCC was already in the midst of its Triennial Review of its unbundling rules. The FCC thus already had a proceeding underway to answer the following kinds of questions that would give economic content to the definition of "impairment." If FCC regulation succeeded in reducing the CLECs' level of "impairment," what variable would we observe changing: Prices? Output? Investment? CLEC profit? Sales of complementary hardware and software? The FCC said that it wanted to review its UNE policies "in light of [its] experience" since $1996 .^{18}$ Experience implies empiricism, and unless the FCC clearly states its hypothesis concerning the predicted effects of its particular unbundling policies, such as the impairment test, it cannot know what changes to expect or the method by which to measure them.

The standard economic metric is consumer welfare, yet that is the one conspicuous variable that the FCC excluded from its laundry list of five factors that were supposed to unpack the phrase "materially diminishes." 19 I submit that no reasonable understanding of "the public interest" can be reconciled with the FCC's exclusion of consumer welfare from the list of relevant considerations. A cynic might speculate that the reason for the omission is that consideration of consumer welfare would vitiate many of the FCC's conclusions on the essentiality of unbundling particular network elements. Consideration of consumer welfare would undo the competitorwelfare standard by which the FCC hoped to straighten the Leaning Tower of Pisa.

In this sense, the unbundling debate illustrates the potential circularity of regulation. "Impairment" cannot be defined without reference to the price regulation to which UNEs are subject. Impairment is thus endogenously determined by UNE price regulation. Moreover, impairment is endogenously affected by the allowed duration of the lease. Under existing TELRIC pricing, would a CLEC be impaired if it were required to lease a UNE for its useful life (more precisely, for the duration of its depreciable life for regulatory purposes), instead of being free to lease the

16 Implementation of the Local Compctition Provisions of the Telecommunications Act of 1996, Third Report and Order and Fourth Further Notice of Proposed Rulemaking, 15 F.C.C.R. 3696, 3725 (1999).

17 United States Telecom Ass'n v. FCC, 290 F.3d 415 (D.C. Cir. 2002).

UNE Triennial Review NPRM, supra note $11, \uparrow 4$.

Id. 19 
UNE for a period that is terminable at will by the lessee and capped by regulators?

Furthermore, what is the fundamental economic characteristic of "impairment?" Increasingly, the bottleneck of the telecommunications network is regarded as the trench in the street. The costliness of digging holes is a breathtakingly unpersuasive justification for mandating the unbundling of telecommunications networks, especially next-generation services. It is regrettable that only a fraction of regulatory energy was devoted to the coordination of the actual trenching and sizing of conduit as was devoted to estimating the forward-looking cost of an unbundled loop in a hypothetical network. A CLEC faces no barrier to entry with respect to the provision of a service if the ILEC itself is overlaying existing facilities or if it is building new facilities or totally rehabilitating previous facilities. The ILEC faces the same sunk cost that a CLEC would. This analysis would seem to answer the FCC's central question in its Triennial Review: should the FCC "modify or limit incumbents' unbundling obligations going forward so as to encourage incumbents and others to invest in new construction[?] ${ }^{20}$

The FCC would clarify the meaning of "impairment" if it assessed the magnitude of the real option conferred on the CLEC by mandatory unbundling of a particular network element at a TELRIC-based price. ${ }^{21}$ The value of the real option held by the CLEC increases with three factors: uncertainty concerning technology, consumer demand, and regulation; the duration of the lease; and the degree to which the leased assets are investments by the ILEC that are sunk rather than salvageable.

The real option view of mandatory unbundling meshes neatly with two of the five factors that the FCC had been using to determine the scope of unbundling - that is, before the D.C. Circuit's May 2002 decision in the U.S. Telecom Association case. ${ }^{22}$ The first factor is, in the FCC's words, "whether the [unbundling] obligation will promote facilities-based competition, investment, and innovation," and the second, again in the FCC's words, is "whether the unbundling requirements will provide uniformity and predictability to new entrants and market certainty in general."23 With respect to the second factor, a lack of uniformity and

$20 \quad$ Id. $\$ 24$.

21 See Hausman \& Sidak, supra note 2; Jerry Hausman, Valuing the Effect of Regulation on New Services in Telecommunications, 1997 BROOKINGS PAPERS ON ECON. ACTIVITY: MICROECONOMICS 1.

22 United States Telecom Ass'n v. FCC, 290 F.3d 415 (D.C. Cir. 2002) (vacating and remanding FCC's impairment test) stayed by No. 00-1012, 2002 WL 31039663 (D.C. Cir. Sept. 4, 2002).

23 UNE Triennial Review NPRM, supra note 11 , I 9. 
predictability will increase the standard deviation of returns for the ILEC, which increases the value of the real option that the ILEC is implicitly forced by the FCC to confer on CLECs. That increased value of the real option represents the value to the CLEC of waiting to see whether the ILEC's investments in new technologies pan out before the CLEC commits itself to making sunk investments in the acquisition of particular UNEs. The real option has the effect of discouraging ILEC investment. To the extent that innovation flows from investment, innovation is jeopardized by a rising value of the real option inherently conveyed to CLECs through mandatory unbundling. ${ }^{24}$

In contrast to such economic analysis, the FCC's definition of "impair" as meaning "materially diminishes" does nothing to reduce the regulatory risk that drives the value of the real option that the ILEC must give CLECs when the FCC mandates unbundling at TELRIC-based prices. A "materiality" standard places enormous discretion in the hands of the regulator, which increases regulatory risk for those making decisions on investment in network infrastructure. That greater risk increases the value of the real option that the FCC forces the ILEC to confer on CLECs.

To its credit, the FCC in 2002 proposed what it called a "more granular statutory analysis" of the unbundling requirements in Section 251 of the Telecommunications Act. That recommendation is consistent with the proposal that Jerry Hausman and I made in $1999 .{ }^{25}$ In our article, we advocate an impairment standard that is product-specific, geographically specific, and limited in duration. In essence, a competitive analysis of each desired network element is required, with an antitrust-style examination of competition in the relevant product and geographic market over the relevant time horizon. This approach, incidentally, is consistent with the new regulatory framework that the European Union has adopted for telecommunications. In that framework, competition law principles (of

24 This line of analysis is directly responsive to the FCC's request in its Triennial Revicw for comments on "whether [the Commission] can balance the goals of Sections 251 and 706 by encouraging broadband deployment through the promotion of local competition and investment in inlrastructure." $I d$. $\$ 23$

25 Hausman \& Sidak, suprn note 2 . Admittedly, a product-specific, geographically specific analysis would require greater administrative resources than a blanket rule that required a particular network element to be unbundled everywhere in the nation. But weighing in the opposite direction are two considerations. First, it may be possible to use the Hausman-Sidak analysis to eliminate a particular network element from the mandatory-unbundling list on a nationwide basis, or very nearly so. Switching would be a leading candidate for such treatment. Second, the purpose of the HausmanSidak inquiry is to produce an unbundling result that maximizes consumer welfare. One might quibble that the proper social welfare function should be the difference betwcen consumer welfare and the transactions costs of regulation. But an unbundling rule that sought only to minimize transactions costs (without regard to the impact on consumer welfare) would be a very constricted interpretation of "the public interest," and not one that would coincidentally protect consumer welfare. 
which consumer welfare maximization is the most elemental) are supposed to guide decisions about what and how to regulate on a sector-specific basis.

Under the Hausman-Sidak test, once the CLEC has demonstrated that the network element meets the basic requirements of the essential facilities doctrine, it would then need to show also that an ILEC could exercise market power in the provision of telecommunications services to end-users in the relevant geographic market by restricting access to the requested network element. Thus, the regulator would mandate unbundling of a network element if, and only if, all of the following conditions exist:

- It is technically feasible for the ILEC to provide the CLEC unbundled access to the requested network element in the relevant geographic market;

- The ILEC has denied the CLEC use of the network element at a regulated price computed on the basis of the regulator's estimate of the ILEC's total element long-run incremental cost;

- It is impractical and unreasonable for the CLEC to duplicate the requested network element through any alternative source of supply;

- The requested network element is controlled by an ILEC that is a monopolist in the supply of a telecommunications service to endusers and that employs the network element in question in the relevant geographic market; and

- The ILEC can exercise market power in the provision of telecommunications services to end-users in the relevant geographic market by restricting access to the requested network element.

In its practical application, this test would replace the FCC's current competitor-welfare standard with a consumer-welfare standard.

The Hausman-Sidak analysis also answers the FCC's request in its Triennial Review for an unbundling framework that incorporates what the Commission calls "intermodal competition." ${ }^{26}$ The test would consider the effect of declining prices and growing subscribership for wireless as a

26 UNE Triennial Review NPRM, supra note $11,9 \mid \uparrow 27-28$ 
factor bearing on the extent to which wireless-wireline displacement, rather than unbundling rules, have impaired CLECs. ${ }^{27}$ The FCC's own statistics show that the number of wired access lines in the United States fell by two million between 2000 and $2001 .^{28}$ In August 2002, Forbes magazine reported on the competitive implications of that fact, ${ }^{29}$ and the New York Times reported that wireless was displacing wireline telephone access. ${ }^{30}$ By early 2002, nearly eighteen percent of Americans considered wireless service to be their primary means of voice communication. ${ }^{31}$ Figure 4 shows the growth of wireless subscribership relative to local access lines.

\section{Figure 4. Wireless Subscribers and Local Access Lines, 1985-2002}

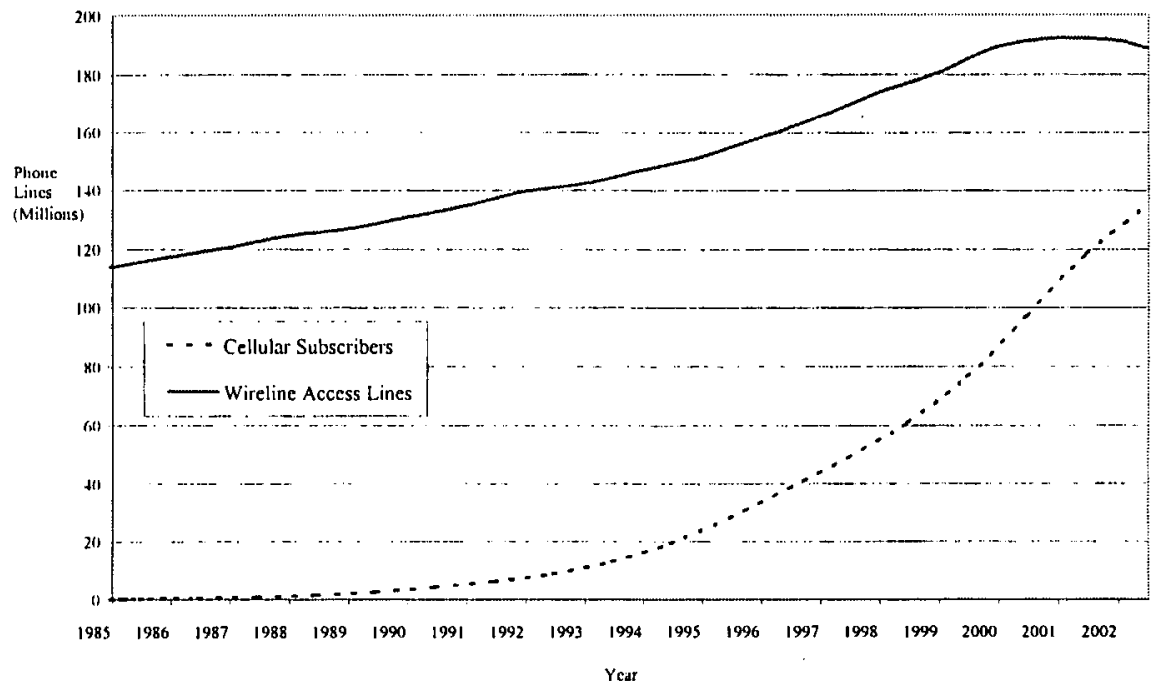

Source: Fed. Communications Comm'n, Trends in Telephone Service (May 2002); Fed. COMmunications COMm'N, Local. Telephone Competition: Status as of June 30, 2002 (Dec. 2002); Cellular Telecommunications \& INTERnEt ass'N, Wireless Industry Survey RESULTS (2002).

27 This analysis is relevant to "the rapid introduction of competition in all markets," which is one of the five factors that the FCC had been using to judge impairment at the time of the U.S. Telecom Association decision. Id. $\$ 21$.

28 FCC, LOCAL TElepHONE COMPETITION: STATUS AS OF DECEMBER 31, $2001 \mathrm{tbl} .5$ (2002); FCC, LOCAL TELEPHONE COMPETITION AT THE NEW MILLENNIUM tbls. 2-3 (2000).

29 Scott Wooley, Bad Connection, ForBes, Aug. 12, 2002, at 84.

30 Simon Romero, When the Cellphone Is the Home Phone, N.Y. TIMES, Aug. 29, 2002, at G1. In addition to noting this growing phenomenon of wireless displacement of landlines, the business press observed in September 2002 that AT\&T Broadband and Cox Communication had signed up over 1.7 million local telephone customers and were adding 60,000 every month, Peter Grant, More Consumers Answer Call of Cable for Phone Service, WALL ST. J., Sept. 5, 2002, at B1.

31 See Implementation of Section 6002(b) of the Omnibus Reconciliation Act of 1993, Annual Report and Analysis of Competitive Market Conditions with Respect to Commercial Mobile Services, Seventh Report, 17 F.C.C.R. 12,985, 13,017 (2002) (citing survey results in Michelle Kessler, 18\% See Cellphones as Their Main Phones, USA TODAY, Feb. 1, 2002, at B1). 
Figure 4 shows that the growth of wireless subscribers exceeded the growth of access lines between 1985 and 2002. Also, between 2000 and 2002 , the growth rate of access lines was negative, whereas the growth rate of cellular subscribers remained positive. It would seem inescapable, therefore, that the wireless industry has stolen customers from the wireline industry. In other words, the local loop bottleneck is not a bottleneck.

Competition occurs on the margin. So why does the FCC not acknowledge that cell phones now substitute for landlines for significant numbers of consumers? Even the Interstate Commerce Commission, the whipping boy of deregulators, managed to acknowledge intermodal competition between railroads, barges, and pipelines in the 1980 s, when it revised its policy on rate regulation for railroads serving captive shippers. ${ }^{32}$

Of course, intermodal competition between wireless and wireline telephony depends critically on the FCC's allocation of sufficient spectrum to accommodate the shift in demand. This dependency on government spectrum allocation is another example of the regulation-induced endogeneity of perceived market failure. Without enough spectrum allocated, the local loop looks like a bottleneck. That appearance of market failure is then considered evidence of the continued need for regulation. In the United States, we have never permitted the necessary counterfactual to come into existence, so as to assess without regulatory endogeneity whether the local loop really is a natural monopoly or an essential facility. If the FCC were to acknowledge the actual and potential displacement of wireline access by wireless, the exercise of mandating the unbundling of incumbent local exchange networks would sooner or later fade away.

On February 20, 2003, as this Article was going to press, the FCC announced its decision in its Triennial Review on unbundling policy. In a 3-2 vote in which Chairman Powell and Commissioner Kathleen Abernathy strenuously dissented from the majority led by fellow Republican, Commissioner Kevin Martin, the FCC announced a new impairment standard to be administered by the state PUCs. The procedure by which the FCC announced this new policy was bizarre, as the agency did not actually have an order to issue at its meeting. Evidently, because of the last-minute negotiations among the commissioners, the FCC voted on a "term sheet" for an order, not an actual draft order. Commissioner Michael

32 See, e.g., Burlington N. R.R. Co. v. Interstate Commerce Comm'n, 985 F.2d 589, 595-99 (D.C. Cir. 1993) (discussing ICC policy of rate regulation of railroads serving captive shippers). 
Copps said in his separate statement: "Although the bottom lines have been decided, the devil is more often than not in the details. I am unable to fully sign on to decisions without reservations until there is a final written product." ${ }^{, 33}$ Clearly, changing a "shall" to "may" here and there in an order running several hundred pages could escape notice but have a substantial impact on the order's practical meaning.

Given, for purposes of administrative procedure, the absence of the text of an order at the time of the February 20, 2003 meeting, it is fair to ask whether the FCC actually issued an order that day. If it did not, the old unbundling rules expired on February 20,2003, pursuant to the lifting of the stay by the D.C. Circuit in the U.S. Telecom Association case. ${ }^{34}$ From that day until the FCC ultimately publishes the text of its Triennial Review order in the Federal Register, only the bare statutory language of Section 251 of the Telecommunications Act defines the government-created rights of CLECs and the government-created obligations of ILECs. Similarly, if the devil is truly in the details, then the commissioners' final agreement on the language of the Triennial Review order would seem to be a different "meeting" for purposes of administrative law, separate from their decision to reduce to writing their broad-brush agreement on "the bottom lines." If so, then this subsequent meeting would trigger the usual public notice and ex parte procedures.

The high school civics rendition of administrative law would posit that Congress, a political body, established the FCC to be an expert independent agency to set telecommunications policy. Because of such agency expertise and independence, the Supreme Court has instructed the D.C. Circuit and other federal appellate courts to defer, through the Chevron doctrine, to the reasoned analysis of an agency like the FCC. The FCC's decision in the Triennial Review, however, plainly was not based on reasoned analysis, as there was no document explaining why various lines were being drawn in one place and not another. The decision exhibited neither expertise nor independence. The commissioners could not be sure what they were voting for, and their statements accompanying the decision radiated politics. The possible dimensions of political struggle in the Triennial Review are multiple: There are the economic interests of the RBOCs in conflict with those of AT\&T and the other CLECs; the

33 Press Release, Michael J. Copps, Commissioner, Federal Communications Commission, Revicw of the Section 251 Unbundling Obligations of Incumbent Local Exchange Carriers, Approving In Part, Concurring In Part, Dissenting In Part 4 (Feb. 20, 2003), available at http:/hraunfoss.fcc.gov/edocs_public/attachmatch/DOC-231344AS.doc.

34 United States Telecom Ass'n v. FCC, 290 F.3d 415 (D.C. Cir. 2002) (vacating and remanding FCC's impairment test) stayed by No. 00-1012, 2002 WL 31039663 (D.C. Cir. Sept. 4, 2002). 
personal ambitions of Commissioner Martin versus those of Chairman Powell; and, even though they seem far fetched, White House concerns about the ramifications of unbundling and TELRIC pricing for the 2004 presidential election. ${ }^{35}$

Given so much politics surrounding what can only be fairly characterized as a desiccated matter of pricing regulation, it is worth asking why Congress needs the FCC at all. Why should Congress delegate the making of transparently political decisions concerning telecommunications to a body whose comparative advantage is not supposed to be politics? Why not leave political decisions with the elected federal legislature? If the FCC's review of mandatory unbundling policy ultimately will turn on politics, why should Congress permit the FCC to waste more than a year compiling a record by which the agency might pretend to have reached its decision by a more disinterested means?

The Triennial Review also incidentally suggests how Chevron can cheapen the constitutional role of the Judiciary with respect to oversight of the administrative state. Agencies and the litigants before them engage in highly strategic use of the administrative process in which the sustainability of regulations on appeal is a major component. If the purpose of appellate review is to determine whether a supposedly expert independent agency has managed to produce one "reasonable" reading of its statute, then how much is really left for appellate judges to do in administrative law? It does not require a penchant for judicial activism to believe that Chevron can diminish the proper role of the Judiciary as the interpreter of acts of Congress. How much deference is due an agency decision like the Triennial Review, which mocks the administrative process?

Turning to the substance of the FCC's decision, the Commission's press release redefined "impairment" such that "[a] requesting carrier is impaired when lack of access to an incumbent LEC network element poses a barrier or barriers to entry . . . which are likely to make entry into a market uneconomic." ${ }^{36}$ This analysis, the FCC said, "specifically considers

35 See Alan Murray, FCC 'Palace Coup' Creates More Work for the Lobbyists, WALL ST. J., Feb. 24, 2003, at A4.

AT\&T's top lobbyist, James Cicconi, a veteran of the first Bush administration, also is said to have encouraged the view that [Commissioner Kevin] Martin['s] plan [to decide the Triennial Review on unbundling] is good politics for President Bush, because it prevents chaos and bankruptcies before the 2004 election. That ld. spawned rumors that it was a coup masterminded by White House aide Karl Rove.

36 Press Release, Federal Communications Commission, FCC Adopts New Rules for Network Unbundling Obligations of Incumbent Local Phone Carriers 1 (Feb. 20, 2003), available at http://hraunfoss.fcc.gov/edocs_public/attachmatch/DOC-231344Al.doc. 
market-specific variations, including considerations of customer class, geography, and service." ${ }^{37}$ The only UNE that the FCC removed from the unbundling list was switching for high-capacity loops (which principally serve business customers), and even that national finding may be rebutted by individual states. ${ }^{38}$ With the exception of high-capacity switching, the new status quo would seem to be that all UNEs still must be unbundled unless the state PUC decides otherwise. It is not clear that there is any time limit on how long a state may take to determine whether to remove a UNE (other than high-capacity switching) from the list of elements subject to mandatory unbundling at regulated prices.

The FCC's new approach to implementing the impairment test (though certainly not its results, judging from the number of UNEs that remain on the unbundling list) sounds compatible with the Hausman-Sidak test, which would evaluate these same kinds of competitive factors on a granular, geographically disaggregated basis. The Hausman-Sidak framework also envisions that the state PUCs have the resources and factfinding experience to assist the FCC in conducting the analysis that is essential to administer the impairment standards with the requisite degree of geographic specificity.

In addition to redefining impairment, the FCC stated that it would modify the calculation of TELRIC in two respects: it would direct the state PUCs to use a higher cost of capital to reflect an ILEC's competitive risk, and it would permit the states to use accelerated depreciation that more closely tracks the useful life of telecommunications equipment. ${ }^{39}$ Both of these adjustments move the calculation of TELRIC (though perhaps only incrementally) in the direction of reflecting the real option value of mandatory access at a regulated price. In other words, using a combination of Chevron deference and the Supreme Court's 2002 TELRIC decision, the FCC may be trying to redefine TELRIC so that new-TELRIC produces higher UNE prices than old-TELRIC. The possible means to do so are as numerous as they are arcane, and they definitely could not be discerned from a press release.

39 Attachment to Press Release, Federal Communications Commission 4 (Feb. 20, 2003), available at http://hraunfoss.fcc.gov/edocs_public/attachmatch/DOC-231344A2.doc.
} 
III. The Collateral Damage to the Telecommunications Industry from WorldCom's Fraud and False Statements

WorldCom's accounting fraud poses a serious question for telecommunications regulators. Over the past twenty years, the principal economic insight in the regulation of network industries has been the asymmetric information between the regulator and the incumbent. The incumbent is typically cast as a dominant firm, if not an outright monopolist in law or fact. The concern over asymmetric information led to both incentive regulation and dominant-carrier regulation. Because the regulator's access to information was imperfect, the dominant carrier was subjected to greater obligations of disclosure, tariffing, and reporting. The proposition that competitors were sophisticated veterans of antitrust and regulatory battles did not fit comfortably within this model.

On September 26, 2002, the former controller of WorldCom pled guilty to criminal fraud in connection with the company's accounting scandal and bankruptcy. ${ }^{40}$ The same day, the Wall Street Journal reported that government reports unintentionally dignified WorldCom's false claim that Internet traffic was doubling every. one hundred days. ${ }^{41}$ The government thus contributed to the hype that caused tens, if not hundreds, of billions of dollars to be invested in long-distance fiber optic networks that go unused. Despite the intensity of the FCC's demands for information from the incumbent carriers, the agency was blindsided by the disaster caused by WorldCom's dissemination of false information.

To appreciate the extent of the harm that WorldCom has caused in the telecommunications industry, it is necessary to understand the breadth of services that the company offers. WorldCom is a major provider of Internet services, which include Internet backbone, hosting, virtual private networks, and wholesale Internet service provider services. ${ }^{42}$ WorldCom's consumer offerings are long-distance service, local service, and prepaid calling cards. WorldCom's business offerings are voice, data, international, and government services. WorldCom's misconduct reached private parties who consume, or supply inputs for, each of these services.

40 WorldCom's Myers To Plead Guilty, WALL ST. J., Sept. 26, 2002, at A3 (reporting that David Myers, former controller of WorldCom, is expected to plead guilty). More guilty pleas soon followed. See Susan Pulliam \& Jared Sandberg, Two WorldCom Ex-Staffers Plead Guilty to Fraud, WALL ST. J., Oct. 11, 2002, at A3 (Betty Vinson, former director of management reporting, and Troy Normand, former director of legal entity accounting).

41 Yochi J. Dreazen, Wildly Optimistic Data Drove Telecoms To Build Fiber Glut, WALL. ST. J. ONLINE, Sept. 27, 2002, at http://online.wsj.com/public/us.

42 See, e.g., EASTERN MANAGEMENT GROUP, Is WORLDCOM TOO BIG TO FAIL? Liquidation COULd IMPRove TEleCOM SECTOR 4 (2003). 


\section{A. False Internet Traffic Reports That Encouraged Overinvestment in Long-Distance Capacity}

Rival telecommunications carriers would have found it reasonable to believe WorldCom's Internet traffic projections because (1) such data are proprietary and WorldCom dominated Internet backbone services, and (2) WorldCom was subject to regulatory oversight and was submitting those same estimates to regulators. WorldCom's competitors subsequently directed billions of dollars in capital expenditures for long-distance and Internet backbone capacity. It is also possible that WorldCom's accounting fraud, which I discuss in the following section, contributed to excessive capital expenditures by WorldCom's competitors.

WorldCom's claim that Internet traffic was doubling every one hundred days misled government officials and the business press. The claim first surfaced in 1996 and has been traced to the chief scientist of UUNet, a subsidiary of WorldCom. ${ }^{43}$ In 1997, WorldCom issued a press release stating that Internet traffic was "almost doubling every quarter." John Sidgmore, the chief executive officer of WorldCom, repeated the claim in $1998 .^{45}$ In September 2000, Kevin Boyne, the chief operating officer of UUNet, told the Washington Post: "Over the past five years, Internet usage has doubled every three months. We're seeing an industry that's exploding at exponential rates." ${ }^{46}$ According to Professor Andrew Odlyzko, WorldCom's executives were "more responsible for inflating the Internet bubble than anyone." ${ }^{47}$ The Appendix to this Article is a chronology of this erroneous "factoid." WorldCom's Internet traffic myth was widely repeated by several important government officials (including Vice President Al Gore, FCC Chairman William Kennard, former FCC Chairman Reed Hundt, Secretary of Commerce William Daley, and Representative Edward J. Markey of the House Telecommunications Subcommittee) and media outlets (including the Financial Times, Business Week, the New York Times, the Washington Post, ABC News, the BBC, $\mathrm{CNN}$, and Reuters).

WorldCom's misrepresentation of the growth of Internet traffic had the air of credibility because data on Internet traffic volumes, unlike data on voice telephone traffic, are regarded to be highly proprietary and consequently are not shared among Intemet service providers or backbone

43 Dreazen, supra note 41

44 The Power of WorldCom's Puff, ECONOMIST, July 20, 2002, at 61.

45 Dreazen, supra note 41.

46 Peter Behr, On or Off the Bandwidth Bandwagon?, WASH. POST, Sept. 24, 2000, at HI.

47 The Power of WorldCom's Puff, supra note 44. 
carriers. When it sought to acquire Sprint's sixteen percent share of the Internet backbone business, WorldCom controlled thirty-seven percent or more of the Internet backbone market. ${ }^{48}$ Consequently, investors, competitors, and the public had good reason to take WorldCom's representation about Internet traffic growth on its face, since the company was uniquely positioned at the time to know this information. WorldCom surely understood how heavily the marketplace and government agencies relied on its Internet traffic reports. In his testimony to Congress in January 2003, Commissioner Michael Copps explained how the FCC is forced to rely on honest reporting by telecommunications carriers:

[W]e must use our current authority to reduce the chance that, in a competitive market, corporate misdeeds and mismanagement will injure American consumers or the competition that Congress sought to promote in the 1996 Act. In light of all the accounting depredations we have witnessed in the financial world regulated by the SEC, we need to reassure ourselves that our own accounting procedures and requirements are in good stead. Our accounting data inform our decisions about the reality of competition and the protection of consumers. ${ }^{49}$

Commissioner Copps argued that the FCC must reduce its dependency on regulated carriers for data:

We have come to rely over the years perhaps too much on self-reported industry data or Wall Street analysts for information to make critical decisions. We must commit to doing the hard work of collecting our own data rather than relying on potentially misleading and harmful financial, accounting, and market information produced by corporate sources subject to clear biases and market pressures. ${ }^{50}$

48 Press Release, U.S. Dept. of Justice, lustice Department Sues To Block WorldCom's Acquisition of Sprint: Unless Blocked, Deal Would Result in Higher Prices for Millions of Consumers (June 27, 2000), available al http://www.usdoj.gov/opa/pr/2000/June/368at.htm ("WorldCom operates the largest internet backbone network, which carries approximately 37 percent of all internet traltic."). The European Commission estimated that WorldCom's share of the Internet backbone market at that time was between 32 and 36 percent. Case COMP/M.1741-MCI WorldCom/Sprint, Commission Decision of June 28, 2000 Declaring a Concentration Incompatible with the Common Market and the EEA Agreement o 116, available at http://europa.eu.int/comm/competition/mergers/cases/ decisions/m1741_en.pdf. Because WorldCom and Sprint formally withdrew their application for Transfer of Control of Licenses and Section 214 Authorizations in July 2000, the FCC was not able to present its market share estimates.

49 Statement of Michael J. Copps, Commissioner, Federal Communications Commission, Before the Senate Committee on Commerce, Science, \& Transportation (Jan. 14, 2003), available at http:/hraunfoss.fcc.gov/edocs_public/attachmatch/DOC-230241A4.doc.

$50 \quad$ Id. 
In retrospect, it appears that WorldCom used this asymmetry of information to exaggerate the value of its stock by overstating the growth in Internet traffic volumes.

WorldCom's misrepresentation of that growth encouraged excessive investment in long-distance capacity. AT\&T Labs reported in 2001 that rival telecommunications carriers made investment decisions in reliance on WorldCom's faulty projections:

Whether Internet traffic doubles every three months or just once a year has huge consequences for network design as well as the telecommunications industry. Much of the excitement about and funding for novel technologies appear to be based on expectations of unrealistically high growth rates. ${ }^{51}$

Some industry analysts attribute much of the enormous decline in market capitalization in the telecommunications sector to WorldCom's misconduct. ${ }^{52}$ The Eastern Management Group found that:

At the time, the returns from the long haul data market seemed almost beyond estimation due to repeated claims of (then market leader) UUNET (later WorldCom) executives that 'Internet traffic was doubling every 90 to 100 days-an assumption that drove much of the overbuilding and proved to be wildly exaggerated. ${ }^{53}$

The Eastern Management Group also determined that a significant percentage of the $\$ 90$ billion invested by carriers in the long-haul industry was misallocated because of WorldCom's false projections. ${ }^{54}$

51 K.G. COFFMAN \& A.M. OdLyzKo, AT\&T LABS, INTERNET GROWTH: IS THERE A "MOORE'S LAW" FOR DATA TRAFFIC 7 (2001), available at http:/www.dtc.umn.edu/ odlyzko/doc/intemet.moore.pdf (citing L. Bruno, Fiber Optimism: Nortel. Lucent, and Cisco Are Battling To Win the High-Stakes Fiber-Optics Game, RED HERRING, June 1, 2000).

52 For an example of analysts' linking Internet growth to excess telecommunications network capacity, see Joelle Tessler, Telecom Companies Struggle with Glut of Fiber-Optic Networks, SAN JOSE MERCURY NEWS, Apr. 13, 2002, at Al (attributing to Scott Cleland, chief executive of the Precursor Group, a telecommunications investment research firm, the view that "[m]uch of the great fiber build-out was based on a big miscalculation" owing to WorldCom).

53 EASTERN MANAGEMENT GROUP, supra note 42, at 2 (quoting Joelle Tessler, WorldCom Spine UUNET is Critical Part of Internet, SAN JOSE MERCURY NEWS, Sept. 1, 2002).

54 Id. 


\section{B. WorldCom 's Accounting Fraud May Have Destroyed Billions of Dollars of Shareholder Value in Other Telecommunications Firms}

WorldCom's accounting fraud harmed telecommunications equipment manufacturers and other telecommunications carriers. WorldCom's accounting restatements may have even contributed to a much broader loss of shareholder value across the equity markets as a whole. In congressional testimony in January 2003, Commissioner Kathleen Abernathy partially attributed the downturn in the telecommunications sector to WorldCom's fraudulent behavior:

Not only did the economy suffer from devalued businesses and widespread layoffs, but several companies-most notably, WorldComappear to have resorted to financial deception to mask poor performance. This fraud compounded the downturn by shaking investors' confidence in the truthfulness of financial statements. ${ }^{55}$

Anecdotal evidence supports Commissioner Abernathy's view, as the financial community blamed WorldCom's financial improprieties for severe market declines in the telecommunications industry. ${ }^{56}$

Empirical evidence also supports Commissioner Abernathy's view that WorldCom's fraud destroyed shareholder value in other telecommunications firms. To estimate the magnitude of that destruction of wealth, I performed an event study. One can use event-study analysis to assess whether the capital market, when controlling for general movement in the broader stock indices, considered WorldCom's accounting errors to be "good news" or "bad news" for rival telecommunications providers. I focused on the reaction of the stock prices of WorldCom's long-distance competitors (AT\&T and Sprint) and U.S. telecommunication equipment manufacturers (Lucent, Nortel, Corning, Cisco, JDS Uniphase, and Tellabs).

My hypothesis is that the market interpreted the announcement of WorldCom's accounting error as "bad news" for the telecommunications industry for a variety of reasons. WorldCom's accounting error likely had

55 Statement of Kathleen Q. Abernathy, Commissioner, Federal Communications Commission, Before the Scnate Committee on Commerce, Science, \& Transportation (Jan. 14, 2003), available at http://hraunfoss.fcc.gov/edocs_public/attachmatch/DOC-230241 A3.doc.

56 Two days after WorldCom's first accounting restatement, one business reporter wrote, "WorldCom Inc.'s disclosure [that] it improperly accounted for $\$ 3.8$ billion in expenses has wreaked much havoc in the financial markets this week," Ross Snel, WorldCom's Pain May Eventually Prove AT\&T's Gain, DOW JONES NEWS SERV., June 28, 2002. According to one investment banker, WorldCom's accounting revisions caused the bond market to be "skittish and paranoid," WorldCom Crash Brings Fear and Loathing to Markets, EUROWEeK, June 28, 2002. 
a negative impact on its long-distance competitors because bad news for one firm may be bad news for other firms in the same market. On the other hand, the financial market may have interpreted the collapse of WorldCom as an opportunity for AT\&T and Sprint to gain market share. Hence, the expected net effect of WorldCom's fraud on its direct competitors is ambiguous. Telecommunication equipment manufacturers' stock prices, by contrast, would have suffered unambiguously from WorldCom's news because the accounting scandal raised doubts about the growth of the telecommunications and Internet market that had been predicted through WorldCom's statements and success. ${ }^{57}$

I used the market model to estimate the predicted returns to a particular company on the event day of June 26, 2002, when WorldCom initially announced a $\$ 3.8$ billion accounting restatement. ${ }^{58}$ The market model is given by the following equation:

$R_{i t}=\alpha+\beta_{i} R_{m t}+\varepsilon_{i t}$

where $R_{i t}$ represents the return to company $i$ on day $t, R_{m t}$ represents the return to the S\&P 500 Index on day $t$, and $\varepsilon_{i t}$ represents an error. ${ }^{59}$ The estimate of $\alpha$, or "alpha," is the average rate of return the stock would expect on a day when the S\&P 500 Index realized a zero return. The estimate of $\beta_{i}$, or "beta," represents the sensitivity of company $i$ 's returns to general market movements, or its "systematic risk." Betas and alphas were estimated using the ordinary least squares method for the market model equation over a 200-trading-day estimation period (which is $t=-$ 250 to -50 , where $t=0$ is the event date, June 26, 2002). The "expected return" of a stock is defined as the stock's estimated alpha plus the product of the actual daily return of the S\&P 500 Index and the stock's estimated beta. I calculated the "abnormal returns" for each firm by subtracting the expected returns from the actual returns. That is, the daily abnormal returns are the residuals for each observation in the regression analysis.

57 One could hypothesize that telecommunications equipment manufacturers experienced negative abnormal returns because they were among WorldCom's creditors. The increased risk of nonpayment to these creditors would arise from the fact that expectations concerning WorldCom's future net cash flows had been revealed to rest on a faise assessment of the company's growth in revenue and profits. That false assessment exaggerated the demand for WorldCom's services, and hence it exaggerated as well the derived demand for the telecommunications equipment that WorldCom and other carriers would need to purchase to provide those services. Hence, this alternative hypothesis is not fundamentally different from the one stated above.

58 Jared Sandberg et al., WorldCom Admits \$3.8 Billion Error in Its Accounting, WaLL ST. J., Junc 26, 2002, at Al.

59 Dividend payments are counted as retums to a particular stock on the ex-dividend date. 
Consider now an unexpected announcement when $t=0$, or the event day. I consider two windows. The first is a window of three days, from one day before the announcement to a day after the announcement. The second is a one-day window that considers the abnormal returns solely on the event day itself. For each window, I compute the cumulative abnormal returns for that period. I also compute abnormal returns for value-weighted portfolios of affected firms. Finally, for each window, I compute the standard errors of the abnormal returns (for each company and each portfolio) by using information covering the 200-day estimation period.

The first news of WorldCom's accounting error came on the evening of June 25, 2002. By the next morning, Nasdaq had suspended trading in WorldCom's stock. WorldCom's stock had closed at 83 cents on June 25, 2002. Trading resumed on July 1, 2002, when WorldCom's stock price opened at 8 cents and closed at 6 cents, an overall decrease of 93 percent. News of WorldCom's revision of its accounting errors was released on the evening of August 8, 2002. That news did not have as great an impact as the initial news of accounting errors, and WorldCom's stock fell from 12.5 cents on August 8, 2002, to 10.94 cents on August 9, 2002-a decrease of 12.5 percent. After the subsequent September estimated revision to the accounting error, WorldCom's stock price fell from 12.11 cents on September 18, 2002, to 11.33 cents on September 19, 2002-a decrease of 6.4 percent. The price movements in WorldCom's stock for the August and September events do not appear to differ from the movements of most stocks that have fallen to "penny-stock" status. Any price change is large in percentage terms. In addition, the last two event dates occurred after WorldCom had declared bankruptcy. Therefore, the market had already assigned a high probability to the prospect that WorldCom's common stock would eventually become worthless, whether or not the firm emerged from bankruptcy. Because investors likely expected WorldCom to revise its earnings after the first disclosure, I do not consider the second and third revision of WorldCom's losses to be event days for the purpose of the event study. The first announcement of WorldCom's accounting errors likely had the greatest impact on other firms' share prices.

Table 1 shows the value-weighted abnormal returns for long-distance providers and equipment manufacturers upon the first news of WorldCom's accounting restatement on June 26, 2002. 
Table 1. Value-Weighted Cumulative Abnormal Returns for U.S. Interexchange Carriers and Telecommunications Equipment Manufacturers upon Initial Announcement of WorldCom's $\$ 3.8$ Billion Accounting Restatement (June 26, 2002)

\begin{tabular}{lccc}
\hline $\begin{array}{l}\text { Cumulative } \\
\text { Abnormal Returns }\end{array}$ & $\begin{array}{c}\text { Interexchange } \\
\text { Carriers } \\
\text { (AT\&T \& Sprint) }\end{array}$ & $\begin{array}{c}\text { U.S. Equipment } \\
\text { Manufacturers }\end{array}$ & $\begin{array}{c}\text { U.S. Equipment } \\
\text { Manufacturers } \\
\text { (excluding Cisco) }\end{array}$ \\
\hline I-Day & $-4.7 \%$ & $-1.8 \%$ & $-12.4 \%$ \\
3-Day & $-5.0 \%$ & $-4.2 \%$ & $-17.6 \%$ \\
Z-Statistic & & & $-4.50^{* * *}$ \\
\hline 1-Day & $-2.13^{* * *}$ & -0.72 & $-3.37^{* * *}$ \\
\hline
\end{tabular}

Source: Author's calculations.

Note: * Significant at the $10 \%$ level. ** Significant at the $1 \%$ level.

Table 2. Cumulative Abnormal Returns for U.S. Interexchange Carriers upon Initial Announcement of WorldCom's Original \$3.8 Billion Accounting Restatement (June 26, 2002)

\begin{tabular}{lcc}
\hline Cumulative Abnormal & \multicolumn{2}{c}{ Interexchange Carrier } \\
Returns & AT\&T & Sprint (FON) \\
\hline 1-Day & $-3.30 \%$ & $-10.20 \%$ \\
3-Day & $-3.40 \%$ & $-12.80 \%$ \\
Z-Statistic & & \\
\hline 1-Day & $-1.31 *$ & $-4.03^{* * *}$ \\
3-Day & -0.9 & $-2.74^{* * *}$ \\
\hline
\end{tabular}

Source: Author's calculations.

Note: * Significant at the $10 \%$ level. *** Significant at the $1 \%$ level.

Table 3. Cumulative Abnormal Returns for U.S. Telecommunications Equipment Manufacturers upon Initial Announcement of WorldCom's Original \$3.8 Billion Accounting Restatement (June 26, 2002)

\begin{tabular}{lllllll}
\hline $\begin{array}{l}\text { Cumulative } \\
\text { Abnormal } \\
\text { Returns }\end{array}$ & Lucent & Nortel & Corning & Cisco & JDS Uniphase & Tellabs \\
\hline 1-Day & $-19.3 \%$ & $-7.9 \%$ & $-14.0 \%$ & $0.4 \%$ & $-10.0 \%$ & $-8.3 \%$ \\
3-Day & $-36.8 \%$ & $-16.0 \%$ & $-15.2 \%$ & $-1.4 \%$ & $-1.4 \%$ & $-7.3 \%$ \\
Z-Statistic & & & & & & \\
\hline I-Day & $-4.95^{* * *}$ & $-2.30^{* *}$ & $-3.21^{* * *}$ & -0.10 & $-2.30^{* *}$ & $-2.20^{* *}$ \\
3-Day & $-5.37^{* * *}$ & $-2.59^{* * *}$ & $-1.94^{* *}$ & -0.28 & -0.20 & -1.09 \\
\hline
\end{tabular}

Source: Author's calculations.

Note: ** Significant at the $5 \%$ level. *** Significant at the $1 \%$ level. 
Table 1 shows that the AT\&T and Sprint portfolio experienced significant negative abnormal returns on both the day of WorldCom's initial announcement and during the three-day window surrounding the announcement. $^{60}$ The disaggregated results in Table 2 show that WorldCom's initial announcement affected Sprint more than AT\&T. Table 1 also shows that the portfolio of U.S. equipment manufacturers experienced negative cumulative abnormal returns over each time period. Table 3 presents disaggregated results. Corning, JDS Uniphase, Lucent, Nortel, and Tellabs experienced significant negative abnormal returns on the day of WorldCom's initial announcement. Corning, Lucent, and Nortel experienced significant negative cumulative abnormal returns during the three-day window surrounding the announcement. Cisco did not experience a statistically significant abnormal return, perhaps because the demand for its principal products (routers) was for some reason less affected by WorldCom's initial announcement than was the demand for the products of the other telecommunications equipment manufacturers. However, because of its large market capitalization, Cisco swamps the results of a value-weighted portfolio of telecommunications equipment manufacturers. For that reason, Table 1 reports findings with and without Cisco included in the value-weighted portfolio of telecommunications equipment manufacturers.

The negative cumulative abnormal returns experienced by AT\&T and Sprint around the date that WorldCom first revealed its accounting problems amounted to $\$ 2.5$ billion in losses in market capitalizations (equal to $\$ 49.2$ billion $*-5.0 \%$ ). The negative cumulative abnormal returns experienced by telecommunications equipment manufacturers around the same date amounted to $\$ 5.3$ billion in losses in market capitalizations (equal to $\$ 127.4$ billion * $-4.2 \%$ ). In other words, event study analysis indicates that WorldCom's accounting fraud destroyed at least $\$ 7.8$ billion of shareholder wealth in other American telecommunication companies.

60 The statistic in an event study is the abnormal return, which is the predicted residual from a least-squares regression. See, e.g., ZVI BODIE, AlEX Kane \& Alan J. MarCuS, InVESTMENTS 339 (4th ed. 1999). In large samples, the residual from a least-squares regression is distributed according to the normal probability distribution. See, e.g., GEORGE G. JUDGE, W. E. GRIFFITHS, R. CARTER HILL, Helmut LutKePoHL \& TSOUNG-ChaO LeE, The THEORY AND PRACTICE OF ECONOMETRICS 153-57 (2d ed. 1985). Dividing a normally distributed random variable by its standard deviation yields a variable with a "standard normal distribution." See, e.g., RICHARD J. LARSEN \& MORRIS L. MARX, AN INTRODUCTION to MATHEMATICAL STATISTICS AND ITS APPLICATIONS 215-16 (2d ed. 1986). A Zscore refers to a particular value along the horizontal axis of the standard normal distribution. There exists a 10 percent probability that a point greater than 1.28 will be drawn from a standard normal distribution, id. at 576-77. Similarly, there exists a five percent probability that a value greater than 1.64 will be drawn from the standard normal, id. Therefore, a Z-score between 1.28 and 1.64 implies statistical significance at the ten percent level of confidence. A Z-score that exceeds 1.64 indicates statistical significance at the five percent level of precision or beyond. 


\section{Incorrect Information Supplied to State and Federal Governments That Was Essential to Formulating Telecommunications Policies}

Reasonable minds can differ over whether telecommunications regulation is excessive or insufficient. But as long as the United States continues to regulate telecommunications at all, it is essential that companies give regulators truthful, complete, and accurate information. Otherwise, the FCC cannot make policies that reflect actual market conditions. Chairman Powell stated in September 2002 that "[r]egulatory accounting data and related information filed by telecommunications carriers is used by federal and state telecommunications policymakers to fulfill various responsibilities, such as determining interstate access charges, evaluating federal-state jurisdictional separations, setting rates for unbundled network elements and calculating universal service support." ${ }^{\prime 61}$ WorldCom must report data on gross billed revenues on an annual and quarterly basis. ${ }^{62}$ Those data are filed on FCC Form 499-A or 499-Q, signed by an officer of the company, along with revenue information collected on FCC Form 159 submitted in September of each year. The Commission uses those data to calculate regulatory fees as well as contributions to support the Universal Service Fund, Local Number Portability Administration, North American Numbering Plan Administration, and Telecommunications Relay Service. ${ }^{63}$ To the extent that WorldCom provided false information, those public programs and services might not be funded appropriately.

WorldCom's false statements to regulators influence the investment decisions of its rivals. For example, WorldCom and MCI have actively participated over the years in FCC proceedings determining whether AT\&T should be released from price regulation or whether the Bell

61 Press Release, Michael K. Powell, Chairman, Federal Communications Commission, Fedcral-State Joint Conference on Regulating Accounting Issues (Sept. 5, 2002), available at http:/hraunfoss.fcc.gov/edocs_public/attachmatch/DOC-225969Al.doc

6247 C.F.R. $\$ \$ 54.706,54.711,54.713,64.604$ (2002). All telecommunications carriers providing interstate telecommunications service, interstate telecommunications providers offering interstate telccommunications for a fee on a non-common-carrier basis, and payphone providers that are aggregators must contribute to the Universal Service Fund and file a Telecommunications Reporting Worksheet annually (on FCC Form 499-A) and quarterly (on FCC Form 499-Q), 47 C.F.R. $\$ \$ 54.706,54.711,54.713(2002)$.

63 Every common carrier providing interstate telecommunications services is required to contributc to the Telecommunications Relay Services ("TRS") Fund on the basis of its relative share of interstate end-user telecommunications revenues. 47 C.F.R. $\$ 64.604$ (2002). The calculations are based on the Telecommunications Reporting Worksheet. 47 C.F.R. $\S 64.604(\mathrm{c})(5)(\mathrm{iii})(\mathrm{B})(2002)$. Moleover, all telecommunications carriers in the United Statcs are required to contribute to the costs of establishing a numbering administration, and the contributions are based on the Telecommunications Reporting Worksheets. 47 C.F.R. $\$ 52.17$ (2002). All telecommunications carriers must contribute to the costs of long-term number portability. 47 C.F.R. $\S 52.32$ (2002). 
companies should be allowed to offer long-distance service. If false or unreliable information in such proceedings skews the FCC's development of regulations, the investment decisions and competitive strategies of telecommunications carriers will also be misdirected, all to the ultimate detriment of consumers.

\section{Can Federal Courts, Regulators, Congress, and Cabinet Departments Trust WorldCom's Filings?}

WorldCom's accounting fraud destroys the company's credibility in proceedings before the federal courts, regulatory commissions, Congress, and cabinet departments. Since 1996, for example, WorldCom has argued to state and federal regulators that the cost of an unbundled loop is much less than incumbent local exchange carriers say it is. Yet a central thrust of the SEC's investigation of WorldCom concerns its understatement of its own costs of local access. Similarly, the costs of interconnection and unbundling are central to the Commission's Triennial Review of local competition policies. The FCC cannot take at face value the representations that WorldCom makes in such a proceeding. The U.S. Trade Representative cannot take at face value what WorldCom says the cost of local interconnection should be in Japan. The Supreme Court cannot take at face value what WorldCom asserts to constitute "impairment" under Section 251. And Congress cannot take at face value what WorldCom claims about the importance of UNE-P for local competition. All those governmental bodies are rightly concerned with the proper meaning of "cost" in local telecommunications, and that is the fundamental question around which WorldCom spun its enormous accounting fraud. All those other governmental bodies are justified in approaching what WorldCom has to say with skepticism, particularly in light of the fact that the New York Times reported that, as recently as January 2003, the carrier was still failing to report its true financial condition. $^{64}$

64 See Seth Schiesel, WorldCom Report Adds to the Size of Its Sales Drop, N.Y. TIMES, Jan. 30,2003 , at $\mathrm{Cl}$ (reporting that "sales at five important divisions of WorldCom, the troubled longdistance communications carrier, withered far faster in the second half of 2002 than the company has publicly reported, according to an internal WorldCom document"). 
IV. Were WorldCom's Fraud and Bankruptcy Intended To Achieve an Anticompetitive Purpose?

The FCC should investigate whether WorldCom's fraud and subsequent bankruptcy had an anticompetitive purpose. In other words, the fraud may have been intended to exploit not only WorldCom's investors, but also its customers and competitors.

\section{A. Repeated Misrepresentation of Financial Performance}

In addition to making the false claims of Internet traffic growth explained above, WorldCom provided the FCC and the SEC with false information regarding line costs and hence earnings. WorldCom subsequently acknowledged that corporate officers and other senior executives knew that those submissions were without foundation. ${ }^{65}$ In its June 2002 complaint against WorldCom, the SEC explained the nature of WorldCom's deceit:

WorldCom reported on its Consolidated Statement of Operations contained in its 2001 Form $10-\mathrm{K}$ that its line costs for 2001 totaled $\$ 14.739$ billion, and that its earnings before income taxes and minority interests totaled $\$ 2.393$ billion, whereas, in truth and in fact, WorldCom's line costs. for that period totaled approximately $\$ 17.794$ billion, and it suffered a loss of approximately $\$ 662$ million. ${ }^{66}$

Hence, WorldCom exaggerated its earnings in 2001 alone by nearly $\$ 3$ billion. WorldCom later admitted that $\$ 3.055$ billion in line costs (which represent fees paid by WorldCom to third parties for network access) were improperly transferred from expense to capital accounts during $2001 .^{67}$ WorldCom further admitted that, despite the company's representations, those transfers did not comply with generally accepted accounting principles. ${ }^{68}$

Since the filing of the SEC's complaint on June 26, 2002, WorldCom admitted additional improprieties in years before 2001. WorldCom admitted that in $1999,2000,2001$, and the first quarter of 2002 , the

65 Press Release, WorldCom, WorldCom Announces Intention To Restate 2001 and First Quarter 2002 Financial Statements (June 25, 2002), available at http://www.worldcom.com/ global/about/news/.

66 Plaintiff's Complaint at 2, Sec. and Exchange Comm'n v. WorldCom, Inc., Case No. 02 CV 4963 (JSR) (S.D.N.Y. June 26, 2002) [hereinafter SEC Complaint].

67 WorldCom, supra note 56.

68 Id. 
company "improperly reported" Hence, the earlier Form 10-Ks that WorldCom submitted to the SEC and FCC for those accounting periods also contained misrepresentations.

\section{B. Fraudulent or False Statements as a Means To Raise Rivals ' Costs}

WorldCom's fraudulent behavior may have raised rivals' costs by inducing inefficient investment in capacity and inefficient expenditures for customer acquisitions. A carrier makes investment decisions based on expected use of its network. If a carrier expects constantly increasing demand, it will invest in capacity. To the extent that carriers relied on WorldCom for information concerning future demand for Internet or longdistance services, those carriers may have made inefficient investment decisions. Because capacity in a telecommunications network is irreversible, the carrier could not downsize in the face of revised expectations. The costs would be forever sunk.

WorldCom's fraud also has likely caused inefficient expenditures for customer acquisition. A carrier expends resources on customer acquisition on the basis of expected profits from winning the customer net of the acquisition costs. An example of such acquisition costs at the residential level is the offer of a $\$ 100$ check to a customer who switches long-distance carriers. As demonstrated above, WorldCom misrepresented its line costs, which are the fees paid by WorldCom to third parties for network access. Because a rival carrier could overestimate the expected profits of acquiring a local customer (equal to the expected revenues less expected line costs), the rival carrier might pay too much for customer acquisition. As with capacity investment, customer acquisition is a sunk cost that cannot be recovered.

If allowed to continue operating as a carrier in good standing with the FCC, WorldCom's deceptive reporting could contaminate the beliefs of the investment community and force competitive carriers to pay higher capital costs. Like most competitive industries, the investment community judges telecommunications carriers on the basis of relative performance. If carrier $A$ 's earnings are growing more slowly than the earning of carrier $B$, then carrier $A$ is considered to be underperforming. Inflating one's books in this setting is analogous to grade inflation among rival academic departments: If one's competitors are exaggerating their performance, then choosing not to inflate your books may result in a lower stock price.

69 Press Release, WorldCom, WorldCom Announces Additional Changes to Reported Income for Prior Periods (Aug. 8, 2002), available at http://www.worldcom.com/global/about/news/. 
Understanding this perverse competition for respectability, investors might discount the reported earnings of all telecommunications carriers, not just the reports by those with tamished reputations. This problem is commonly recognized in the economics literature as the "lemons problem." As defective cars drove out good cars from the used car market in Nobel laureate George Akerlof's famous example ${ }^{70}$ fraudulent carriers might drive out honest carriers in the telecommunications industry. The result would be higher capital costs for the surviving carriers and less investment in the telecommunications network.

\section{Reduced Cost of Capital and Facilitation of Acquisitions}

A firm's cost of capital is the expected return on a portfolio of all of that firm's securities. ${ }^{71}$ If WorldCom had preferential access to capital because of its fraudulent accounting, then the firm's cost of capital would be lower than it otherwise would be, all other factors being equal. ${ }^{72}$ By exaggerating its earnings, WorldCom may have lowered its average borrowing rate owing to the false impression that WorldCom would cover its loans. WorldCom also could have lowered its beta (or sensitivity of its stock price to changes in the market index), which in turn would have lowered its average return on equity. This artificial reduction in WorldCom's cost of capital helped it to make a series of costly acquisitions of long-distance, Internet backbone, local telephone, paging, and web application/hosting companies. WorldCom paid for the acquisitions with its own inflated stock. $^{73}$ Table 4 summarizes WorldCom's acquisitions from December 1996 through July 2001.

As Table 4 shows, from December 1996 through July 2001, WorldCom spent $\$ 66.5$ billion in acquisitions. Had the Department of Justice approved the firm's offer for Sprint, WorldCom would have spent $\$ 195$ billion on acquisitions.

70 George A. Akerlof, The Market for "Lemons": Quality Uncertainty and the Market Mechanism, 84 Q.J. ECON. 488 (1970).

71 See Richard a. Brealey \& Stewart C. Myers, Principles of Corporate Finance 457 (4th ed. 1996).

72 This conclusion follows from a priori economic reasoning. It could be difficult, however, to establish this proposition empirically because one cannot yet say (for purposes of time-series analysis) when the fraud at WorldCom began. Therefore, it is not possible to compare WorldCom's cost of capital during a fraud-free period with its cost of capital during the fraud.

73 See, e.g., Kurt Eichenwald, Corporate Loans Used Personally, Report Discloses, N.Y. TIMES, Nov. 5, 2002, at $\mathrm{Cl}$ (discussing the results of the initial report by former Attorney General Dick Thomburgh, WorldCom's bankruptcy examiner). 
The Failure of Good Intentions

Table 4. WorldCom Acquisitions, December 1996-July 2001

\begin{tabular}{|c|c|c|c|c|}
\hline Date & Target & $\begin{array}{c}\text { Price } \\
\text { (billions) }\end{array}$ & Business & $\begin{array}{l}\text { Approved? } \\
\text { (Yes/No) }\end{array}$ \\
\hline Dec. 1996 & MFS, UUNet (1) & $\$ 12.5$ & $\begin{array}{l}\text { Internet access options, } \\
\text { applications, and value- } \\
\text { added services }\end{array}$ & Yes \\
\hline Jan. 1998 & Brooks Fiber (2) & $\$ 2.4$ & Facilities-based CLEC & Yes \\
\hline Jan. 1998 & CompuServe (3) & $\$ 1.3$ & $\begin{array}{l}\text { Internet service } \\
\text { provider }\end{array}$ & Yes \\
\hline Jan. 1998 & $\begin{array}{c}\text { ANS } \\
\text { Communications } \\
\text { (3) }\end{array}$ & $\$ 0.5$ & $\begin{array}{l}\text { Internet service } \\
\text { provider }\end{array}$ & Yes \\
\hline Aug. 1998 & Embratel (3)* & $\$ 2.3$ & $\begin{array}{l}\text { Brazilian long-distance } \\
\text { provider }\end{array}$ & Yes \\
\hline Sept. 1998 & $\mathrm{MCl}(3)$ & $\$ 40.0$ & Long-distance service & Yes \\
\hline Oct. 1999 & Sprint (4) & $\$ 129.0$ & Long-distance service & No \\
\hline Oct. 1999 & SkyTel (5) & $\$ 1.7$ & Paging service & Yes \\
\hline \multirow[t]{2}{*}{ July 2001} & Digex (3) & $\$ 5.8$ & $\begin{array}{l}\text { Web/application } \\
\text { hosting service }\end{array}$ & Yes \\
\hline & Total Approved: & $\$ 66.5$ & & \\
\hline
\end{tabular}

Sources: (1) WORLDCOM, INC., SEC FORM 10-K405/A, at 3 (tilled Apr. 26, 2001); (2) WorldCom/Brooks Fiber: Brooks Holders To Get 1.85 Shares, DOW JONES NEWS SERV. (Jan. 30, 1998); (3) WORLDCOM, INC., SEC FORM 10-K405, at 2 (filed Mar. 13, 2002); (4) WORLDCOM, INC., SEC FORM 10-K, at 6 (filed Mar. 30, 2000); (5) Matt Moore, SkyTel shareholders approve merger with MCI WorldCom, ASSOClated PRESS NEWSWIRES (Scpt. 30, 1999); (6) WorldCom Gains Control of Digex Through Merger with Intermedia, PR Newswire (Sept. 5, 2000).

Notes: * WorldCom acquired 19 percent of Embratel.

\section{During the Pre-bankruptcy Period, WorldCom's Fraud Facilitated a Business Strategy That May Have Been Designed To Harm Rival Providers of Internet Backbone or Long-Distance Services}

Before its bankruptcy, WorldCom's business strategy may have been designed to use the company's accounting fraud to harm rival producers. Because WorldCom's real costs were unknown, its pricing of Internet backbone services bore no relation to cost. Unlike standard applications of predation theory, recoupment of losses in the instant case was unnecessary because WorldCom's management had other ways to profit personally and because Chapter 11 bankruptcy was readily available if the strategy failed. 
WorldCom's strategy may be novel, but it was not irrational. And, in any event, novelty and irrationality are not defenses to the antitrust laws.

1. Because WorldCom's Real Costs Were Unknown, Its Pricing of Internet Backbone Services Bore No Relation to Cost and Thus Served To Distort Competition

It is entirely plausible that WorldCom priced its Internet backbone service below its actual long-run average incremental cost ("LRAIC"). WorldCom was reporting lower costs than it actually incurred. In his first report as the court-appointed Examiner of the WorldCom bankruptcy, former Attorney General Dick Thornburgh observed that over the course of five quarters in 2001 and 2002 WorldCom "took the brazen and radical step of converting substantial portions of its line cost expenses into capital items;" a step that overstated capital investment and understated expenses. $^{74}$ WorldCom's rivals could not detect that WorldCom was engaged in predation. WorldCom's rivals were forced to cut their prices and possibly incur actual losses on their books or forfeit market share to a rival whose lower prices were not the result of superior efficiency. According to Sprint's former chairman and chief executive officer, William Esrey, the pressure to compete in the market, and to match the growth claimed by companies that later turned out to be falsifying their accounting, pushed telecommunications companies into unreasonable expansion, foolish investments, and unsustainably low pricing. Esrey notes "[w]e kept asking ourselves what we were doing wrong because we couldn't generate the numbers WorldCom reported .... As we discovered, the margins were a hoax but the devastating effect on our industry was very, very real." 75 That deception explains how WorldCom could use "low-ball" bids to secure lucrative government contracts. If competitors were bidding on the basis of actual costs, while WorldCom was bidding on the basis of fictitious costs, the most efficient carrier would not necessarily win the bidding.

For example, in 2001, before WorldCom admitted that it was falsifying its books, WorldCom earned $\$ 1.7$ billion, or eight percent of its revenue, from state and federal government contracts. ${ }^{76}$ In November

74 WorldCom, Inc., First Interim Report of Dick Thornburgh, Bankruptcy Court Examiner, Case No. 02-15533 at 8 (Bankr. S.D.N.Y.) (Nov. 4, 2002) [hereinafter Thormburgh Report].

75 Stacy Cowley, Sprint CEO Blasts WorldCom, IDG NEwS SERVICE, Oct. 2, 2002 (quoting William Esrey's keynote address at Intemet World), available $a t$ http://www.nwfusion.com/ ncws/2002/1002sprintceo.html (last visited Oct. 8, 2002).

76 Christopher Stem, WorldCom Wins Another U.S. Contract; Third Award in Two Months Reflects Government's Confidence in Firm, WASH. POST, Dec. 20, 2002, at E5. 
2002, the federal government awarded WorldCom a contract to provide telecommunications services for veterans hospitals. ${ }^{77}$ In the same month, WorldCom also won an extension of a contract with the General Services Administration ("GSA") to provide long-distance telephone service for seventy-seven federal agencies, a deal that WorldCom reported was worth $\$ 331$ million per year. ${ }^{78}$ In December 2002, WorldCom was awarded a contract to provide global communications services to the State Department, a concession reportedly worth up to $\$ 360$ million over ten years. ${ }^{79}$ To the extent that WorldCom can or did reduce its competitors' output by fraudulently winning government contracts, it is plausible that WorldCom possessed and continues to exert the power to discipline competitors or induce them to exit the industry.

This manifestation of market power is unfamiliar to telecommunications regulators and antitrust enforcers. But the fact that this unprecedented strategy does not fit comfortably within traditional economic theories of anticompetitive behavior in no way mitigates its demonstrated injury to economic efficiency and the competitive process.

2. Recoupment of Losses Was Unnecessary as a Condition for Plausible Predation by WorldCom Because Its Management Had Other Ways To Profit Personally

WorldCom's management did not need the company to recoup predatory losses by subsequently raising prices. ${ }^{80}$ This feature of predation by WorldCom is in direct contrast to the scholarship ${ }^{81}$ and jurisprudence ${ }^{82}$ on predatory pricing by private firms, which has emphasized that, after the exit or disciplining of competitors or the prevention of entry, the dominant firm will raise its price high enough above the competitive level for a long enough time to recoup the earlier profit sacrifice and more. The key insight with respect to WorldCom is that a divergence of interests developed between the company's shareholders and management. Consequently,

77 Id.

78 Id.

$79 \quad$ Id.

80 Traditional predation models usually have assumed recoupment of short-run losses. For a review, see Jean TIROLE, The Theory of INDUSTRIAl Organization 373 (1992); Janusz A. Ordover \& Garth Saloner, Predation. Monopolization, and Antitrust, in 1 HANDBOOK OF INDUSTRIAL ORGANIZATION 537 (Richard Schmalensee \& Robert D. Willig eds., 1992).

81 See Phillip Areeda \& Donald F. Turner, Predatory Pricing and Related Practices Under Section 2 of the Sherman Act, 88 HARV. L. REV. 697 (1975); William J. Baumol, Predation and the Logic of the Average Variable Cost Test, 39 J.L. \& ECON. 49 (1996). (1993).

82 See Brooke Group Ltd. v. Brown \& Williamson Tobacco Corp., 509 U.S. 209, 221-25 
WorldCom's management had the opportunity to devise strategies by which to benefit privately from a pricing policy that might never have envisioned that WorldCom would recoup its losses from pricing without regard to cost.

By analogy, economists and policymakers have recognized that public enterprises may not need to recoup predatory losses. ${ }^{83}$ The Organization for Economic Cooperation and Development has drawn the distinction that, in the case of a public enterprise, predatory pricing is a subset of "distortionary" pricing, which does not necessarily require conventional recoupment of losses:

It is convenient . . to tabel pricing below cost as "distortionary." "Predatory" pricing is a temporary form of distortionary pricing. Even where distortionary pricing does not lead to prices subsequently being raised above cost, it may still be of public policy concern, because of the effect on productive efficiency. Distortionary pricing might induce a more efficient firm to leave or to not enter the competitive market. ${ }^{84}$

One can extend this reasoning to WorldCom's case, where a serious principal-agent problem decoupled shareholders' interest in profit maximization 'from management's interest in personal wealth maximization.

WorldCom's managers could have personally benefited without recoupment of losses in three ways. First, insiders may have sold WorldCom stock (or tipped others to sell) in anticipation of the stock's collapse. Second, WorldCom may have extended sweetheart loans to WorldCom's senior executives that were collateralized by WorldCom stock. At the time of WorldCom's bankruptcy, Mr. Ebbers owed the company more than $\$ 400$ million in personal loans having long repayment terms and interest rates of 2.18 to 2.21 percent. ${ }^{85}$ The Financial Times reported that "[ $\mathrm{t}] \mathrm{he}$ loans were made to cover a series of margin calls on personal loans Mr. Ebbers had guaranteed with his significant WorldCom

83 See COMmitTeE on COMPETITION LAW AND POLICY, ORGanization for ECONOMIC Cooperation and Development, Promoting Competition in POSTal Services (Series Roundtables on Competition Policy No. 24, DAFFE/CLP(99)22, Oct. 1, 1999); JOHN R. LOTT, JR., are Predatory Commitments Credible? Who Should the Courts Believe? (1999); J. GREgory SidAK \& DANIEL F. SPULBER, PROTECTING COMPETITION FROM THE POSTAL MONOPOLY 116 (1996); John R. Lott, Jr., Predation by Public Enterprises, 43 J. PUB. ECON. 237 (1990); David E. M. Sappington \& J. Gregory Sidak, Are Public Enterprises the Only Credible Predators?, 67 U. CHI. L. REV. 271 (2000); DAvid E. M. SAPPINGTON \& J. GREgORY SidAK, COMPETITION LAW FOR STATEOWNED ENTERPRISES (AEl Working Paper, Dec. 2002); David E. M. Sappington \& J. Gregory Sidak, Incentives for Anticompetitive Behavior by Public Enterprises, REV. INDUS. ORG. (forthcoming 2003).

84 COMMITTEE ON COMPETITION LAW AND POLICY, supra note 83, at 55

85 Stephanie Kirchgaessner, Ebbers Set To Clear His Desk at WorldCom, FIN. TimES, Oct. 29,2002 , at 30 (London ed.). 
shareholding." 86 As of December 2002, Mr. Ebber had not repaid the loan. ${ }^{87}$ In addition, Mr. Ebbers himself personally loaned $\$ 650,000$ to his chief operating officer, Ron Beaumont, whom WorldCom's board relieved of operating responsibilities on October $1,2002 .^{88}$ Since its bankruptcy, WorldCom has been forced to sell, among other assets, a shipyard and the largest cattle ranch in Canada, both of which Mr. Ebbers purchased with loans from WorldCom that were collateralized by his stock in the company. ${ }^{89}$

Third, given how WorldCom's business strategy affected the market value of its competitors, WorldCom's management had the opportunity to take long or short positions in the securities of other telecommunications companies so as to exploit the market-moving potential of WorldCom's false statements. It is not obvious that such trades would constitute unlawful insider trading.

WorldCom's fraud may have been purposefully designed to depress the share values of potential acquisition targets. If so, WorldCom could have benefited in two ways. First, the company would have lowered its acquisition costs. Second, it would have enhanced its own valuationgenerally a result of WorldCom's using acquisitions to boost earnings through pooling-of-interest accounting. ${ }^{90}$ This strategy, of course, would not require a divergence of interests between WorldCom's management and shareholders.

86 Stephanie Kirchgaessner, Sullivan 'Could Testify Against Ebbers', FIN. TIMES, Nov. 13, 2002, at 22 (London ed.).

87 See Stephanie Kirchgaessner, Bernie Ebbers Could Get Tax Brenk on College Gift, FIN TIMES, Dec. 9, 2002, at 28 (London ed.).

88 See Stephanie Kirchgaessner \& Richard Waters, WorldCom Strips Executive of Operating Responsibilities, FIN. TIMES, Oct. 2, 2002, at 17 (London ed.).

89 See Susan Pulliam et al., Easy Money: Former WorldCom CEO Built An Empire on Mountain of Debt, WALL ST. J., Dec. 31, 2002, at Al.

90 In a pooling-of-interests acquisition, the book values of the assets and liabilities of the acquired firm are consolidated with those of the acquiring firm. See, e.g., CLYDE P. STICKNEY \& ROMAN L. WEIL, FinaNCIAL ACCOUNTING 624 (9th ed., 2000). WorldCom accounted for its acquisitions of $\mathrm{MCl}$ Communications Corp., Intermedia Communications Inc., CompuServe Corp., ANS Communications as purchases, but accounted for its acquisitions of Skytel Communications and Brooks Fiber Properties, Inc. as pooling-of-interests. WORLDCOM INC., 2001 SEC FORM 10-K, at 2-4 (Mar. 13, 2002); see also Dale Wettlaufer, WorldCom Hoping for Pooling in Merger Accounting, at http://www.fool.com/LunchNews/1997/LunchNews971008.htm (stating that if it recognized the purchase of $\mathrm{MCl}$ as a pooling-of-interests transaction, WorldCom's "reported earnings would be about $28 \%$ higher than under a purchase treatment"). 
3. The Coordinated Actions of WorldCom's Management, Its Investment Bankers, and Its Auditors May Have Injured Competition in the Telecommunications Industry

WorldCom's management, its investment bankers, and its auditors may have conspired in a manner that unlawfully restrained trade." Competition can suffer even when conspiracies occur among parties that do not compete against one another in the relevant market. Hence, although they obviously do not supply Internet backbone or long-distance services, WorldCom's auditors and its investment bankers still could have directly injured competition in the telecommunications industry by participating in agreements with WorldCom's management that had the effect of facilitating WorldCom's fraud. ${ }^{92}$ Figure 5 shows how each party stood to benefit from two possible conspiracies.

As Figure 5 shows, Salomon Smith Barney, one of WorldCom's principal investment bankers, may have supplied WorldCom's management false and misleading equity research for public dissemination, as well as preferred participation in initial public offerings ("IPOs") of other companies, in exchange for lucrative investment banking work. ${ }^{93}$ Attorney General Thomburgh reported to the bankruptcy court in

$91 \quad$ See 15 U.S.C. $\$ 1(2000)$.

92 The fact that parties to an agreement happen to compete in wholly different markets from one another would not preclude a finding that there existed a conspiracy in violation of Section 1 of the Sherman Act, 15 U.S.C. $\$ 1$ (2000). The Fifth Circuit, for example, has recognized that, even when conspirators who are not competitors of the victim have no interest in curtailing competition in a market in which they do not compete, "when they have been enticed or coerced to share in an anticompetitive scheme, there is still a combination within the meaning of [Section 1] of the Sherman Act." Spectators' Communication Network, Inc. v. Colonial Country Club, 253 F.3d 215, 221 (5th Cir. 2001); see also Perington Wholesale, Inc. v. Burger King Corp., 631 F.2d 1369, 1377 (10th Cir. 1979) ("The fact that [the defendant's] coconspirators competed in markets different from [the defendant's] market does not preclude finding a conspiracy to monopolize [the defendant's] market."). For purposes of doctrinal antitrust analysis, a possible conspiracy between WorldCom and Salomon Smith Barney does not differ from the garden-variety vertical agreement (between a distributor and a retailer, for example). A conspiracy in violation of Section I need not be, to borrow Judge Richard Posner's paraphrasing of George Bernard Shaw, "the vertical expression of a horizontal desire." Valley Liquors, Inc. v. Renfield Importers, Ltd., 678 F.2d 742, 744 (7th Cir. 1982). It is sufficient that the common scheme has an anticompetitive effect. See, e.g., McLain v. Real Estate Bd., 444 U.S. 232, 243 (1980) ("[I]n a civil action under the Sherman Act, liability may be established by proof of either an unlawful purpose or an anticompetitive effect."); United States v. United States Gypsum Co., 438 U.S. 422, 436 n.13 (1978) (noting same)

93 On September 3, 2002, the Wall Street Journal reported:

Mr. [Jack] Grubman [of Salomon Smith Barney], who earned an average of $\$ 20$ million a year during recent years, and received a severance package of about $\$ 30$ million, has been criticized for staying wildly bullish on many telecommunications company clients of Salomon-including WorldCom, Inc., Global Crossing Ltd., and Winstar Communications Inc.-even as their troubles deepened. . . The close relationship between Mr. Grubman and WorldCom has drawn special scrutiny in the wake of confirmation last week that Salomon allocated hard-to-get IPO shares 


\section{Figure 5. Possible WorldCom Conspiracies in Restraint of Trade}

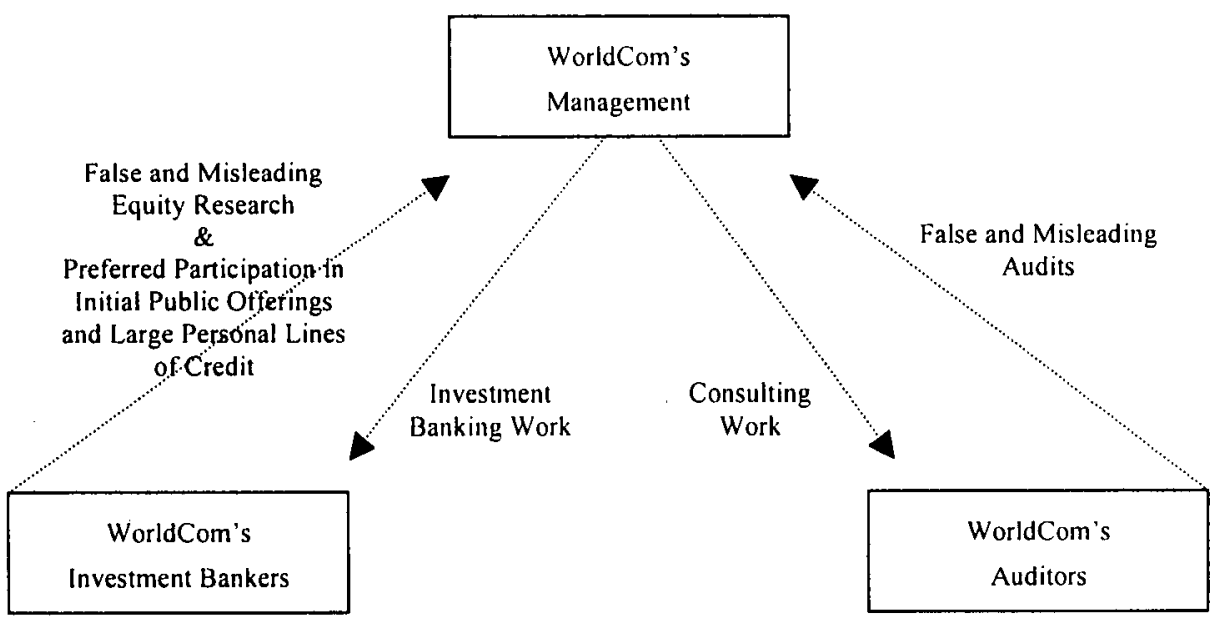

November 2002 that he had found evidence that Jack Grubman, the lead telecommunications equity analyst at Salomon Smith Barney, had "alerted [WorldCom] ahead of time to the questions he would ask in conference calls between securities analysts and WorldCom management." $94 \mathrm{Mr}$. Thornburgh also reported that his examination would continue to investigate "the wildly enthusiastic analyst reports issued by [Salomon

to WorldCom executives and directors, such as former CEO Bernard Ebbers, who made millions of dollars in profits when the stocks shot up.

Charles Gasparino, Salomon Probe Includes Senior Executives, WALL ST. J., Sept. 3, 2002, at C1; see also Susanne Craig, Offerings Were Easy Money for Ebbers, WALL ST. J., Sept. 3, 2002, at Cl (reporting on the House Financial Service Committee's investigation into whether Salomon Smith Barney won investment-banking work from WorldCom by issuing WorldCom executives shares of "hot IPOs" that it was underwriting). A subsequent Wall Street Journal story specifically addressed Salomon Smith Barney's "buy" recommendation on WorldCom:

Mr. Grubman kept his "buy" on WorldCom as it slid to $\$ 4$ from $\$ 64.50$, not downgrading it until a week before the company ousted founder Bernard Ebbers [in the spring of 2002]. Meanwhile, over four years Salomon collected \$107 million in fees for advising WorldCom on 23 deals, says [New York Attorney General Elliot] Spitzer's suit [against WorldCom]. Although Mr. Grubman was so close to WorldCom that he helped plan its strategy, he has said he saw no sign of the $\$ 7$ billion accounting fraud now engulfing the company.

Charles Gasparino et al., WildCard: Citigroup Now Has New Worry: What Grubman Will Say, WALL ST. J., Oct. 10, 2002, at Al. During the summer of 2002, the National Association of Securities Dealers ("NASD") initiated an enforcement proceeding against Mr. Grubman. See Charles Gasparino, NASD Prepares Action Against a Star Analyst, WALL ST. J., July 22, 2002, at Al ("DNASD's decision to pursue regulatory action against Mr. Grubman] marks the first major crackdown by federal securities regulators investigating how big securities firms obtained investment-banking business with overly rosy stock picks.").

94 Thornburgh Report, supra note 74 , at 7. 
Smith Barney] and others with respect to WorldCom at a time when the stock was plummeting." ${ }^{" 95}$ Based on his examination as of November 2002, Mr. Thomburgh reported: "In the transactions we have reviewed to date, [Salomon Smith Barney] and its predecessors, Salomon Brothers and Smith Barney, collectively received more engagements from WorldCom than any other investment banking firm during the past five years. ${ }^{196}$

Similarly, WorldCom's auditor, Arthur Andersen, may have provided WorldCom's management false and misleading audits in exchange for lucrative consulting work. ${ }^{97}$ In his November 2002 report, Mr. Thornburgh questioned "the extent to which Arthur Andersen should have done more to determine whether the risks of abuses were adequately taken into account by the Company's internal control systems, most pointedly its internal audit function." 98

In addition, to increase the likelihood of keeping WorldCom's investment banking work, conglomerate financial institutions may have supplied WorldCom's chairman, Bernard Ebbers, and the company's other senior executives with hundreds of millions of dollars of personal credit lines that were inadequately collaterized with those managers' individual holdings of WorldCom stock. Mr. Ebbers obtained over $\$ 800$ million in personal loans from conglomerate financial institutions over a period of seven years, using his personal holdings of WorldCom stock as collateral. ${ }^{99}$ Citigroup lent $\mathrm{Mr}$. Ebbers $\$ 499$ million in 1999 for the purchase of timberland. At the time, this amount represented more than thirty-five percent of Mr. Ebbers' total worth, and Mr. Ebbers had already used his holdings of WorldCom stock as collateral for sizeable loans from other financial institutions. ${ }^{100}$ In total, Citigroup lent Mr. Ebbers $\$ 552$

$95 \quad$ ld.

96 Id. at 82.

97 According to the Wall Street Journal, a WorldCom executive notified Arthur Andersen in 2000 that the company was improperly accounting for expenses, yet the practice continued undiscovered by Arthur Andersen for two years. Yochi J. Dreazen \& Deborah Solomon, WorldCom Alerts About Accounting Went Unheeded, WALL ST. J., July 15, 2002, at A3.

98 Thomburgh Report, supra note 74 , at 51.

99 See Pulliam et al., supra note 89. Mr. Ebbers used his loans to purchase, among other things, a soybean plantation, a 500,000 acre cattle ranch (the largest private ranch in Canada), 460,000 acres of timberland, a shipyard, and a 132-foot yacht christened "Aquasition," and WorldCom lent Mr. Ebbers $\$ 415$ million to pay back some of these loans when declines in WorldCom's stock price prompted margin-calls from certain banks. Id. According to an interim report by a federal bankruptcy examiner, however, $\$ 27$ million of those loans from WorldCom were used by Ebbers for personal reasons, including the construction of a $\$ 1.8$ million private home and $\$ 3$ million in gifts and loans to friends and family. Eichenwald, supra note 73.

100 See Pulliam et al., supra note 89. Mr. Ebbers' total worth is taken from Forbes' 1999 list of the 400 Richest Americans, which is available at http://www. forbes.com/lists/2003/02/26/ billionaireland.html. 
million, of which over $\$ 450$ million had not been repaid by the end of $2002 .{ }^{101}$

Either of the possible conspiracies depicted in Figure 4 would reflect the serious principal-agent problem between WorldCom's management and its investors. The conspiracies would have eliminated the need for WorldCom's management to recoup losses from any predatory strategy directed at rivals in the long-distance market or Internet backbone market. Put differently, WorldCom's managers would gain despite the fact that WorldCom's shareholders would never recoup the company's losses.

V. The FCC's Unique Obligation To Investigate WorldCom's Harm to the Telecommunications Industry

In January 2003, FCC Chairman Michael Powell gave Congress his policy agenda for the new year. An important component, if not the centerpiece, of that agenda was the Commission's "Triennial Review" of local competition policies. ${ }^{102}$ Conspicuously absent from Chairman Powell's written testimony, however, was any mention of WorldCom's fraud and bankruptcy. At a minimum, that omission implies that the adjudicatory implications of WorldCom's fraud take a backseat to the rulemaking questions of unbundling and access pricing. At a deeper level, the omission suggests that at least some key decisionmakers at the Commission do not recognize even now that unbundling and access pricing rules are intimately related to the substance of WorldCom's fraud. Because WorldCom is one of the two largest CLECs in the United States, the FCC cannot change unbundling and access pricing policies without directly affecting WorldCom's financial condition. ${ }^{103}$

101 Pulliam et al., supra note 89 ; see also Kirchgaessner, supra note 85 and accompanying text. Attorney General Thornburgh reported in November 2002:

When Mr. Ebbers left WorldCom [in 2002], the [company's Compensation] Committee negotiated, and the Company approved, a severance package that included a cash payment of $\$ 1.5$ million per year for life, lifetime medical and life insurance, lifetime use of a corporate jet and conversion of approximately $\$ 408$ million in demand notes into 5-year non-callable $\mathrm{crm}$ notes with a significant annual interest rate subsidy. Thomburgh Report, supra note 74 , at 65 .

102 Competition Issues in the Telecommunications Industry: Hearing Before the Senate Comm. on Commerce, Science, and Transportation, 108th Cong. (2003), available at http:/hraunfoss.fcc.gov/edocs_public/attachmatch/DOC-230241A1.pdf (statement of Michael K. Powell, Chairman, Federal Communications Commission).

$103 \mathrm{MCl}$ reported that it acquired over I million subscribers in its Neighborhood Plan as of October 2002. See Press Release, WorldCom, MCI Welcomes Arkansas to the Neighborhood (Oct. 8, 2002), at http://www.worldcom.com/global/aboutnews. As of January 2003, AT\&T claimed that it had acquired over two million households. See Press Release, AT\&T, AT\&T to Offer Residential Local Service in Washington, D.C. (Jan. 13, 2003), at http://www.att.com/news. 


\section{A. After Chapter II Reorganization, WorldCom Could Underprice Efficient Rivals}

Using Chapter 11 bankruptcy to lower costs cannot induce exit among one's rivals in an industry that lacks economies of scale or network effects. If higher-cost rivals can survive with miniscule market share, then the predatory strategy fails. On the other hand, if a critical share of customers is necessary to remain viable, predation becomes a plausible means to discipline rivals or induce their exit. Because the Internet backbone market exhibits both economies of scale and network effects, the loss of customers due to higher costs (and hence higher prices) can be fatal for a carrier. Even if the target of predation itself declares Chapter 11 bankruptcy, it will struggle to compete effectively against WorldCom in future periods.

WorldCom's continued operation after Chapter 11 reorganization would artificially depress prices for long-distance and Internet backbone services below their true cost of production. In a well-functioning market, prices adjust until demand aligns with supply. Overcapacity arises when supply exceeds demand. To eliminate excess capacity, prices must fall. If capacity is fixed and durable in nature, as is a fiber-optic network, then it cannot be eliminated from the market. Instead, falling prices induce the least efficient firms to exit first, selling their companies or assets to the more efficient survivors.

Which carriers does the FCC wish to see as the survivors? Even if the FCC declines to answer that question, it still has made a choice. Longdistance carriers and providers of Internet backbone services enjoy economies of scale. Price must exceed marginal cost to recover fixed costs. If WorldCom, having shed the fixed cost of its debt, emerges from bankruptcy, it could underprice efficient competitors. Lack of capacity would not constrain WorldCom's acquisition of market share. The severity of the excess capacity plaguing the telecommunications industry is well known. According to one account by the Wall Street Journal, only three percent of the fiber-optic capacity in the United States was being used in May 2001. ${ }^{104}$

WorldCom's continued operation after Chapter 11 reorganization would depress prices for long-distance and Internet backbone services. Although low prices are tempting for policymakers, economic efficiency would suffer because consumers would pay less than the true social cost required to supply the services offered by WorldCom. In the long run,

104 Gregory Zuckerman \& Deborah Soloman, Telecom Debt Debacle Could Lead to Losses of Historic Proportions, WALL ST. J., May 11, 2001, at A1. 
consumers would forgo the benefits from innovation and investment that flow from efficiently priced telecommunications services. Robert $W$. Crandall argues that the FCC would run a significant risk of sending the entire telecommunications industry into a spiral of bankruptcies akin to the rail industry in the mid-1800s and the airline industry in the $1980 \mathrm{~s} .{ }^{105}$

If excess capacity must be taken off the market, it would be unjust and inefficient for it to be AT\&T's or Sprint's because WorldCom's reorganization drove them under. Why should AT\&T and Sprint shareholders suffer because of WorldCom's accounting fraud? And how would the FCC propose to keep the next bankrupt carrier afloat?

\section{B. Chapter 11 Reorganization as State Aid in Violation of Article 87 of the European Community Treaty}

WorldCom's reorganization under Chapter 11 has implications for international telecommunications. The European Union outlaws state aid within its common market. Under Article 87 of the European Community Treaty, "any aid granted by a Member State or through State resources in any form whatsoever which distorts or threatens to distort competition by favoring certain undertakings or the production of certain goods shall, insofar as it affects trade between Member States, be incompatible with the common market." 106 The underlying objective of the prohibition against state aid is to prevent trade from being affected by advantages granted by public authorities, which, in various forms, distort or threaten to distort competition by favoring certain undertakings or certain products. ${ }^{107}$

The phrase "or through State resources" might encompass actions by the U.S. government that affect commerce within the European Community. If the European Union were to take that interpretation, then it is entirely possible that the competitive advantage that a reorganized WorldCom would have in Europe would constitute state aid in violation of Article 87 . The state aid would take the form of the American bankruptcy court's elimination of WorldCom's debt (in whole or part) as part of the reorganization plan. As discussed earlier, the economies of scale in telecommunications imply that WorldCom's ability to shed debt would

105 Robert W. Crandall, WOUld a DebT-Free WorldCOM Wreck THE TElecom INDUSTRY? (Working Paper, 2002). Similarly, Professor Todd Zywicki has argued that the "traditional bankruptcy approach of looking at a company's bankruptcy in isolation is not possible in the telecom industry because these bankrupt firms have a competitive impact on each other." Ron Orol, Domino Effect, THE DAILy DEAL, Jan. 16, 2003, at 27 (quoting Professor Todd Zywicki of George Mason University).

106 Consolidated Version of the Treaty Establishing the European Community, 1997 O.J. (C 340) 173, 208.

107 See, e.g., Case C-39/94, SFEI v. La Poste, 1996 E.C.R. I-3547, at \ 58. 
dramatically reduce its costs relative to the costs of competitors that otherwise would be equally or more efficient. The relevant standard under Article 87 is distortion of competition, which obviously differs from the more demanding monopolization standard in American antitrust law. ${ }^{108}$ One can make little dispute that WorldCom's artificial cost advantage resulting from its reorganization under Chapter 11 would "threaten[] to distort competition" in European telecommunications markets, even if that state-conferred advantage did not have the effect of reducing or destroying competition.

\section{The Differing Responsibilities of the Securities and Exchange Commission, the Bankruptcy Court, and the FCC}

An opaque process could result from the FCC's failure to place WorldCom's fraud squarely on its agenda for 2003. The Commission can proceed, in its Triennial Review, to rewrite unbundling and access pricing as if WorldCom will remain a legitimate competitor in the local telecommunications market. Yet that rulemaking approach implicitly assumes that the Commission has already determined that WorldCom is still qualified to hold its licenses.

To make matters worse, it is more likely than not that regulators would coddle a reorganized WorldCom, lest they fail by allowing it to collapse a second time. The ramifications would be serious for innocent parties. The Commission can sculpt the arcane contours of general policies affecting the ILECs and the CLECs--such as price regulation of an already competitive market for switched access or the restatement of TELRIC pricing principles for unbundled network elements-so as to give WorldCom an implicit bailout. For example, on the day that the FCC announced the outcome of its Triennial Review on unbundling policy, the New York Times reported that "what appears to be emerging will be regulations that give something to each sector of the phone industry and do not further hurt the ailing long-distance providers-AT\&T and WorldCom - as they had feared, at least until after the 2004 election." ${ }^{109}$ The ILECs, of course, would bear the burden of that hidden bailout in the form of lower prices for access to their networks than they otherwise would receive if one of the two largest CLECs were not bankrupt and in danger of liquidation.

108 See, e.g., United States v. Microsoft Corp., 253 F.3d 34 (D.C. Cir. 2001).

109 Stephen Labaton, F.C.C. Ruling Is Expected To Favor Bells, N.Y. TimES, Feb. 20, 2003, at $\mathrm{Cl}$; see also Murray, supra note 35 . 
The Securities and Exchange Commission ("SEC") and the bankruptcy court are not proxies for the FCC, as neither is empowered to eradicate anticompetitive business models or to establish policy for the telecommunications infrastructure. Chapter 11 bankruptcy can be used to lower a firm's cost structure relative to its competitors' cost structure. Applied here, Chapter 11 bankruptcy is used by WorldCom to lower the relative long-run average incremental cost ("LRAIC") of its network. With a lower LRAIC, the firm emerging from Chapter 11 bankruptcy could price its services below its competitors' costs to capture market share. ${ }^{110}$ Despite the short-term lower prices, consumers would be worse off in the long term because efficient firms would be forced to exit or forfeit market share.

Clearly, the bankruptcy court is not responsible for preventing that anticompetitive outcome. The Bankruptcy Code provides legal processes by which a failed business is provided with an opportunity to reorganize its financial affairs so that the business can continue for the benefit of its creditors. ${ }^{11}$ The Bankruptcy Code also provides a framework for distribution if the plan contemplates liquidation. ${ }^{122}$ The bankruptcy court's mandate is the fair and efficient administration of the Bankruptcy Code with respect to the conflicting interests of the debtor and its creditors. Consumers and the competitive process are not within the bankruptcy court's purview. Nor are they within the SEC's purview. The main role of the SEC is to protect investors in securities and to maintain the integrity of the securities markets through disclosure of important information and efficient administration of the Securities Act of 1933 and the Securities Exchange Act of $1934 .{ }^{113}$ Moreover, neither the bankruptcy court nor the SEC would be qualified to establish policy for the telecommunications infrastructure even if either tried to do so.

Congress gave the FCC the unique mandate to promote "a rapid, efficient, Nation-wide, and world-wide wire and radio communication service with adequate facilities at reasonable charges." 114 Accordingly, the agency is empowered to regulate communications by wire and by radio. The duty to guard the welfare of consumers and preserve competition

110 Because the telecommunications industry is characterized by large fixed costs and negligible marginal costs, the textbook rule of marginal-cost pricing does not apply. See William J. Baumol \& David F. Bradford, Optimal Departures from Marginal Cost Pricing, 60 AM. ECON. REV. 265 (1970).

111 See, e.g., In re Eagle Bus Mfg., 158 B.R. 421 (Dist. Ct. S.D. Tex. 1993).

112 Century Glove, Inc. v. First Am. Bank of N.Y., 860 F.2d 94, 102 (3rd Cir. 1988).

113 Sec. \& Exchange Comm'n, The Investor's advocate: How the SEC Protects INVESTORS AND MAINTAINS MARKET INTEGRITY, $a t$ http://www.sec.gov/about/whatwedo.shtml. 11447 U.S.C. \$151(2000). 
among producers of telecommunications services falls squarely on the FCC. Plainly, neither the SEC nor the bankruptcy court has the responsibility and expertise to investigate the competitive ramifications of WorldCom's fraud and bankruptcy.

Wireless communications require a license, and even the common carriage of voice and data over wired networks must get certified. ${ }^{115}$ Some common carriers use wireless, so they need both a certificate and a license. In practical terms, the FCC's power to regulate comes from its power to deny or condition certification or licensure. By statute, wireless licensees must have "character" as a basic qualification. ${ }^{116}$ The FCC has written lengthy policy statements on the conduct that constitutes a lack of good character. ${ }^{17}$ Criminal behavior is not required.

Although character issues usually have involved radio or television broadcasters, the FCC has investigated wireless common carriers as well. ${ }^{118}$ The FCC refused to license a company that concealed the fact that it started building towers for microwave transmission before the agency had approved their construction. ${ }^{119}$ The FCC has said that "where there has been a pattern of deliberate misrepresentation, revocation is the only appropriate remedy." ${ }^{20}$ The closest analogy to WorldCom may be a series of cases from the late 1980s involving RKO, an established broadcaster that lost its radio and television stations (or was forced to sell them at distressed prices) because of misconduct that demonstrated a lack of good character. ${ }^{21}$ Nothing that RKO did can approach the billions of dollars of harm that WorldCom's accounting fraud appears to have caused other telecommunications carriers and equipment manufacturers.

$115 \quad$ Id. $\$ 214$.

$116 \quad$ Id. $\$ 308(\mathrm{~b})$.

117 Policy Regarding Character Qualifications in Broadcast Licensing, Amendment of Part 1, the Rules of Practice and Procedure, Relating to Written Responses to Commission Inquiries and the Making of Misrepresentations to the Commission by Applicants, Permittees and Licensees, and the Reporting of Information Regarding Character Qualifications, 7 F.C.C.R. 6564 (1992).

118 Policy Regarding Character Qualifications in Broadcast Licensing; Amendment of Rules of Broadcast Practice and Procedure Relating to Written Responses to Commission Inquiries and the Making of Misrepresentations to the Commission by Permittees and Licensees, 1 F.C.C.R. 421,424 (1986) ("[C]ommon carriers are distinguished from broadcasters for purposes of character qualifications because no content rcgulation is involved and because such issues are adjudicated on a case-by-case basis without the guidance of a specific policy statement. As a result, reference is occasionally made in common carrier cases to broadcast policies and precedents as aids in resolving character issues."). For an example of a recent revocation proceeding, see Application of Alee Cellular Communications, 17 F.C.C.R. 3237 (2002).

119 TeleSTAR, Inc., 3 F.C.C.R. 2860 (1988)

120 Revocation of the Licenses of Pass Word, Inc., 86 F.C.C.2d 437, 449 | 29 (1981).

121 See, e.g., RKO Gen'l, Inc. (KHJ-Telcvision), 3 F.C.C.R. 5057 (1988). 
VI. Revocation and Liquidation as the Proper Result

If the FCC did strip WorldCom of its licenses and certifications, the company would lose its value as a going concern and probably be forced into Chapter 7 liquidation. The FCC might wish to avoid that outcome in the belief that consumers would benefit from the agency's preserving a competitor in the market. That reasoning would be mistaken, for the result would be the introduction of a "failing-competitor welfare standard" at the FCC. It is implausible to expect consumers to benefit from FCC policies that were predicated on keeping failing competitors in the market. It is unlikely that consumers of long-distance and Internet services would suffer harm if WorldCom exited the market and its assets were sold to other carriers.

\section{A. The Negligible Social Cost from WorldCom's Demise as a Going Concern}

As noted earlier, WorldCom was a patchwork of acquisitions. Attorney General Dick Thomburgh reported to the bankruptcy court in November 2002 that the company "did not achieve its growth by following a predefined strategic plan, but rather by opportunistic and rapid acquisitions of other companies." ${ }^{22}$ This rapid growth had a detrimental effect on the integration of WorldCom's acquisitions: "The unrelenting pace of these acquisitions caused the Company constantly to redefine itself and its focus. The Company's unceasing growth and metamorphosis made integration of its newly acquired operations, systems and personnel much more difficult." 23 So it would be no surprise if few economies of integration were sacrificed by WorldCom's Chapter 7 liquidation rather than its Chapter 11 reorganization. In August 2002, the Washington Post described how "poorly WorldCom absorbed the companies, gaining their revenue but doing little to integrate them operationally to eliminate overlapping costs." ${ }^{24}$ The Eastern Management Group compared WorldCom to a shopping mall:

WorldCom is, in fact, more a shopping mall of products and services rather than a department store. Like many large enterprises, WorldCom's history is rooted in merger and acquisition, but unlike global behemoths like Deutsche Bank and Sony, or even the company's industry peers,

122 Thomburgh Report, supra note 74, at 6, 58-63.

123 Id. at 6.

124 Jonathan Krim, Fast and Loose at WorldCom, WASH. PoST, Aug. 29, 2002, at Al. 
Verizon and SBC, WorldCom has done little to integrate its divisions and operating units into a monolithic entity. ${ }^{125}$

The same report concluded that the "disembodiment of WorldCom could be effected without jeopardizing or compromising national security, the Internet, network service reliability, or the telecom sector as a whole.",26 Industry analysts eventually discerned WorldCom's failure to generate efficiencies from its collection of companies. ${ }^{127}$ One analyst in February 2003 described the aggregation of WorldCom's acquisitions as being "like a bowl of spaghetti." "If WorldCom could not realize economies of integration across its companies, then the disaggregation of those companies through Chapter 7 liquidation would not cause any appreciable loss of efficiencies.

Furthermore, the FCC should consider whether fraud has rendered WorldCom's brand name worthless. Brand names have value when they credibly signal a firm's good reputation. ${ }^{129}$ In WorldCom's case, its brand name signals deceit. The brand name is worthless-if not an actual liability on WorldCom's balance sheet-because of the taint of fraud. WorldCom's new chief executive officer admitted as much in January 2003, when he revealed that he was considering changing the company's name. ${ }^{130}$ On March 13, 2003, WorldCom wrote off all of its goodwill-a total of $\$ 45$ billion. ${ }^{131}$ At the same time, the company wrote down its property and equipment and its intangible assets from $\$ 44.8$ billion to $\$ 10$ billion. ${ }^{132}$ Of that write-off, $\$ 39.2$ billion was property and equipment. ${ }^{133}$

Sunk costs are, of course, sunk costs. Nonetheless, it says something significant in economic terms that WorldCom's new management would

25 EASTERN MANAGEMENT GROUP, supra note 42, at 3.

126 Id. at 1.

127 See MERrill LYNCH, WORLdCOM Group 4 (Jan. 4, 2002); cf. MORGAN STANLEy DeAN WITTER, WORLDCOM GROUP 3 (October 15, 2001).

128 Christopher Stern, WorldCom To Lay Off 5,000 More Employees, WASH. POST, Feb. 4, 2003, at E5 (quoting Susan Kalla, telecommunications analyst at Friedman, Billings, Ramsey Group Inc.); see also id. (attributing to Ms. Kalla the view that "[w]hen WorldCom gobbled up competitors in the 1990 s, it did not integrate the separate networks into a single opcration")

129 See, e.g., Benjamin Klein \& Keith Leffler, The Role of Market Forces in Assuring Contractual Performance, 89 J. POL. ECON. 615(1981).

130 Christopher Stem, WorldCom CEO Rolls Out Turnaround Plan, WASH. POST, Jan. 15, 2003, at E2 ("[WorldCom's new CEO, Michael] Capellas also said ycsterday that WorldCom will eventually change its name in an effort to separate itself from its now-tainted past.").

131 WorldCom, Inc., Press Release, WorldCom Completes Preliminary Review of Goodwill, Intangibles, and Property Equipment (Mar. 13, 2003), available at http://www.worldcom.com/global/news/news $2 . x \mathrm{ml}$ ?newsid=7212\&mode=long\&lang=en\&width=530 \&root=/global/.

$132 \mathrm{Id}$.

$133 \mathrm{Id}$ 
write off a brand name that surely had been the object of millions of dollars of advertising and promotion in recent years. Such a decision supports the conclusion that the value of WorldCom as a going concern is less than the value of the sum of its (devalued) assets.

\section{B. Other Carriers Could Competitively Supply WorldCom's Customers}

With so much excess capacity in long-distance networks, other carriers will eagerly court WorldCom's customers. ${ }^{134}$ Telephone solicitations at dinnertime are not likely to cease, and many of WorldCom's large business customers surely have relationships with backup suppliers of telecommunications services. Moreover, between December 1999 and April 2003 the Bell operating companies ("BOCs") received regulatory approval to provide in-region interLATA service in thirty-eight states-that is, long-distance service from one "local access and transport area" to another, within the region in which the BOC is the incumbent provider of local service. ${ }^{135}$ As Figure 6 shows, those interLATA authorizations enable the BOCs to reach seventy-seven percent of the nation's access lines.

134 See Stephanie Kirchgaessner, WorldCom Set To Restate Dollars 2 bn of Its Accounts, FIN. TIMES, Sept. 20, 2002, at 27 (London ed.) ("While [WorldCom's] bondholders have said the additional [accounting] restatements do add uncertainty to the company's future prospects, they are more concerned with WorldCom's ability to retain contracts and not lose customers."). Cf. Stephanie Kirchgaessner, WorldCom Cuts UK Jobs as Cash Reserves Dwindle, FIN. TIMES, Sept. 17, 2002, at 21 (London ed.) ("On a conference call to senior executives in August [2002], Lucy Woods, senior vicepresident of [WorldCom's] intcmational operations, said the group was having difficulty attracting new customers.").

135 As of March 31, 2003, the states and dates of Section 271 authorization were: Alabama (Sept. 18, 2002), Arkansas (Nov. 16, 2001), California (Dec. 19, 2002), Colorado (Dec. 23, 2002), Connecticut (July 20, 2001), Delaware (Sept. 25, 2002), Florida (Dec. 19, 2002), Georgia (May 15, 2002), Idaho (Dec. 23, 2002), lowa (Dec. 23, 2002), Kansas (Jan. 22, 2001), Kentucky (Sept. 18, 2002), Louisiana (May 15, 2002), Maine (June 19, 2002), Massachusetts (Apr. 16, 2001), Mississippi (Sept. 18, 2002), Missouri (Nov. 16, 2001), Montana (Dec. 23, 2002), Nebraska (Dec. 23, 2002), North Dakota (Dec. 23, 2002), New Hampshire (Sept. 25, 2002), New Jersey (June 24, 2002), New York (Dec. 22, 1999), North Carolina (Sept. 18, 2002), Oklahoma (Jan. 22, 2001), Pennsylvania (Sept. 19 , 2001), Rhode Island (Feb. 24, 2002), South Carolina (Sept. 18, 2002), Tennessee (Dec. 19, 2002), Texas (June 30, 2000), Utah (Dec. 23, 2002), Vermont (Apr. 17, 2002), Virginia (Oct. 30, 2002), Washington (Dec. 23, 2002), and Wyoming (Dec. 23, 2002). See RBOC Applications To Provide InRegion InterLATA Services Under \$27l, at http:/www.fcc.gov/Bureaus/Common_Carrier/inregion_applications. 
Figure 6. Nationwide Percentage of Access Lines Addressable by BOC In-Region InterLATA Service Since Enactment of the Telecommunications Act of 1996

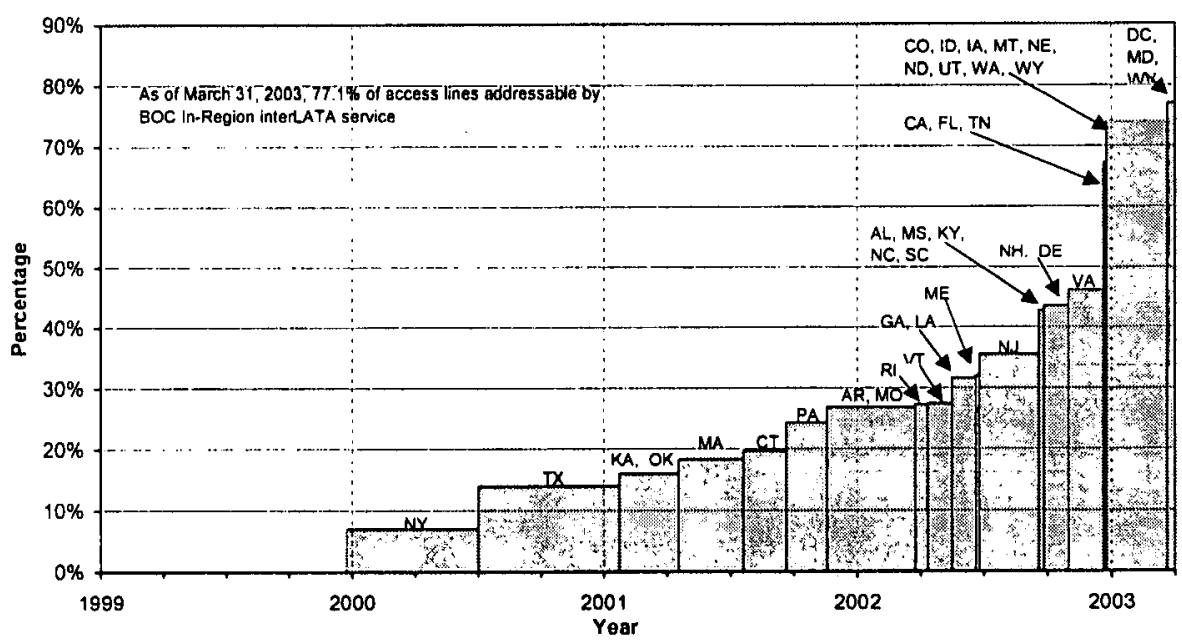

Sourccs: Federal COMmUNiCATIONS COMmission, LoCAL TELEPHONE COMPETITION: STATUS AS OF JUNE 30, 2002 (2002); RBOC Applications, supra note 135.

Note: Percentages calculated using the number of end-user lines served by reporting ILECs and CLECs as of June 30, 2002. Because Alaska, Puerto Rico, and the Virgin Islands are not served by Bell companies and are thus not subject to interLATA regulation, they are excluded from these calculations. The FCC does not disclose the number of CLEC access lines for Arkansas, Delaware, Hawaii, Idaho, Kentucky, Maine, Montana, Nevada, New Mexico, North Dakota, South Dakota, Vermont, West Virginia, and Wyoming. The number of CLEC access lines in these states is assumed to be zero.

The BOCs are thus well positioned to replace WorldCom as competitors to AT\&T and Sprint. Indeed, by January 2003 Verizon had already surpassed Sprint as the third largest interexchange carrier in the United States-even though Verizon had not yet received Section 271 authorizations for the District of Columbia, Virginia, and West Virginia. ${ }^{136}$

Moreover, as the FCC has recognized in other proceedings, the WorldCom network will still exist even after liquidation, should a completely new entrant want to buy all or part of the network and light its dark fiber. ${ }^{137}$ The Commission has recognized that the same reasoning

136 Press Release, Verizon, Verizon Now Third Largest Long-Distance Company (Jan. 7, 2003), $a t$ http://newscenter.verizon.com/proactive/newsroom/release.vtml?id=78494.

137 Implementation of the Non-Accounting Safeguards of Sections 271 and 272 of the Communications Act of 1934, 11 F.C.C.R. 18,877, 18,943 \137(1996). 
applies with equal force to spectrum. Even if WorldCom were to surrender its licenses, it would not cause the corresponding spectrum to evaporate. ${ }^{138}$ Consequently, the telecommunications marketplace will have no less capacity-wireline or wireless-than it does today. ${ }^{139}$

\section{Lessons Learned}

There is a familiar saying in Washington: "there is enough blame to go around." The idea seems to be that individual culpability is inversely related to the size of the debacle. When some government policy goes horribly awry in the United States, it is rarely the case, as it is in the United Kingdom, that a senior official promptly resigns. High-profile government positions in the United States are perceived to have only a professional upside.

While the U.S. telecommunications industry lies enervated, the FCC is again occupied with the question of which network elements an ILEC must unbundle under legislation enacted seven years ago. And despite the WorldCom accounting fraud and bankruptcy, the Commission evidently misses the irony in its pronouncements about what an incumbent's forward-looking costs of operating a hypothetical telecommunications network would be.

Ethical conduct is essential to creating the trust that permits markets to function-let alone to function with the extraordinary efficiency that has long distinguished the American markets for goods and services, for capital, and for labor. WorldCom violated that trust. WorldCom's fraud is the largest deception ever perpetrated in the telecommunications industry. In addition to harming its investors, WorldCom harmed the telecommunications industry. It is appropriate for the FCC to act. Since Congress passed the Telecommunications Act of 1996, the FCC has routinely questioned the accuracy of information supplied to it by incumbent local exchange carriers, whose networks it was trying to open to competition. Yet the FCC was oblivious to the largest accounting fraud in history, committed by a principal beneficiary of those very marketopening efforts. WorldCom's accounting fraud and false statements distorted competition and investment in the telecommunications industry. If, for whatever reason, the Commission turns a blind eye to WorldCom's

138 Applications of Voicestream Wireless Corp., Powertel, Inc., Transferors, and Deutsche Telekom AG, Transferee, for Consent To Transfer Control of Licenses and Authorizations Pursuant to Sections 214 and 310 (d) of the Communications Act, 16 F.C.C.R. $9779 \$ 90$ (Apr. 27, 2001).

139 Purchasers of WorldCom's assets would likely employ some of WoridCom's former employees. Certainly WorldCom employees have the most experience operating WorldCom's networks. 
misconduct, then the agency will aid and abet that misconduct after the fact. The FCC will compound the harm from WorldCom's misconductand add conscious neglect to the agency's previous inattention--if it allows the company to emerge from Chapter 11 reorganization without ever having to answer this fundamental question: How does it serve the public interest for the FCC to allow WorldCom to continue holding its licenses and authorizations? The FCC has a duty to determine promptly whether WorldCom must surrender its licenses and authorizations. If so, regulators should not interfere if the capital markets soon cause WorldCom to cease to exist.

What did seven years of good intentions teach us? At least three things. First, the journey from regulation to a truly deregulated market is costly, and the alternative of managed competition is surely costlier. Second, a consumer-welfare approach to the mandatory unbundling of telecommunications networks would have been simpler, more intellectually coherent, and more beneficial to society than the competitorwelfare standard that has permeated FCC policy from 1996 through 2002. Third, policy makers who cling to caricatures of incumbents and competitors risk missing the big picture.

Let me conclude by invoking the wisdom of Jim Quello, who served two decades as an FCC commissioner. He is widely credited with saying, "What this industry needs is a whole new set of clichés." It is reminder of the failure of good intentions that audiences in 2002 groaned at that quip instead of laughing. Let us hope that it does not take another seven years for the joke to evoke laughter once more. 
The Failure of Good Intentions

\section{APPENDIX 1: CHRONOLOGY OF REPORTING OF WORLDCOM'S INTERNET TRAFFIC MYTH}

\begin{tabular}{|c|c|c|c|}
\hline DATE & $\begin{array}{l}\text { PARTY MAKING } \\
\text { CLAIM }\end{array}$ & NOTES & SOURCE \\
\hline 1996 & $\begin{array}{l}\text { UUNet (Subsidiary of } \\
\text { WorldCom since } \\
\text { 1996)-Michael O'Dell } \\
\text { (then UUNet's Chief } \\
\text { Scientist) }\end{array}$ & $\begin{array}{l}\text { The origin of the } \\
\text { statement. Michael } \\
\text { O'Dell estimated that } \\
\text { network traffic was } \\
\text { doubling every } 100 \text { days } \\
\text { and said "the capacity } \\
\text { crunch is real and will } \\
\text { continue for quite some } \\
\text { time. . . Demand will } \\
\text { far outstrip supply for the } \\
\text { foreseeable future." } \\
\text { Statement by U.S. } \\
\text { Commerce Department } \\
\text { was based on this. }\end{array}$ & $\begin{array}{l}\text { Yochi J. Dreazen, Wildly Optimistic } \\
\text { Data Drove Telecom to Build Fiber } \\
\text { Glut, THE WALL ST. J. ONLINE, Sept. } \\
\text { 26, 2002, available at } \\
\text { http://online.wsj.com/article_print/0,SB } \\
1032982764442483713,00 . h \text { tml. }\end{array}$ \\
\hline 1997 & WorldCom & $\begin{array}{l}\text { Press release referring to } \\
\text { Internet traffic "almost } \\
\text { doubling every quarter" }\end{array}$ & $\begin{array}{l}\text { The Power of WorldCom 's Puff, THE } \\
\text { ECONOMIST, Jui. 18, 2002, available at } \\
\text { http://www.economist.com/printedition/ } \\
\text { displayStory.cfm?Story_ID }=1234733 \text {. }\end{array}$ \\
\hline 1997 & Inktomi Corp. & $\begin{array}{l}\text { The first formal mention } \\
\text { of the statistic. Michael } \\
\text { O'Dell quoted. (White } \\
\text { Paper, 1997). }\end{array}$ & $\begin{array}{l}\text { Yochi J. Dreazen, Wildly Optimistic } \\
\text { Data Drove Telecom To Build Fiber } \\
\text { Glut, THE WALL ST. J. ONLINE, Sept. } \\
\text { 26, 2002, available at } \\
\text { http://online.wsj.com/article_print/0,SB } \\
1032982764442483713,00 . \mathrm{html} \text {. }\end{array}$ \\
\hline $\begin{array}{l}15 \text { Apr. } \\
1998\end{array}$ & $\begin{array}{l}\text { U.S. Department of } \\
\text { Commerce }\end{array}$ & $\begin{array}{l}\text { Study entitled "The } \\
\text { Emerging Digital } \\
\text { Economy" cited the } \\
\text { statistic reported by } \\
\text { WorldCom. }\end{array}$ & $\begin{array}{l}\text { ADVISORY COMMISSION ON } \\
\text { ELECTRONIC COMMERCE, THE } \\
\text { EMERGING DIGITAL ECONOMY (1998), } \\
\text { available at } \\
\text { http://www.ecommercecommission.org/ } \\
\text { EDEreprt.pdf. }\end{array}$ \\
\hline $\begin{array}{l}16 \text { Apr. } \\
1998\end{array}$ & Washington Post & $\begin{array}{l}\text { Reporting on study by } \\
\text { U.S. Commerce } \\
\text { Department. }\end{array}$ & $\begin{array}{l}\text { John M. Berry, Not All Figures } \\
\text { Compute in a Digital Economy, WASH. } \\
\text { POST, Apr. 16, 1998, at El. }\end{array}$ \\
\hline $\begin{array}{l}16 \mathrm{Apr} \\
1998\end{array}$ & USA Today & $\begin{array}{l}\text { Reporting on study by } \\
\text { U.S. Commerce } \\
\text { Department. }\end{array}$ & $\begin{array}{l}\text { Elizabeth Weise, Net Use Doubling } \\
\text { Every /00 Days, USA TODAY, Apr. 16, } \\
\text { 1998, at 1A. }\end{array}$ \\
\hline $\begin{array}{l}16 \text { Apr. } \\
1998\end{array}$ & Las Vegas RJ & & $\begin{array}{l}\text { Ted Bridis, Report: Internet Growth } \\
\text { Soaring, LAS VEGAS RJ, Apr. 16, } 1998 .\end{array}$ \\
\hline $\begin{array}{l}16 \text { Apr. } \\
1998\end{array}$ & Minnesota Daily & & $\begin{array}{l}\text { Internet Revolution Reaches More } \\
\text { People with Each Day, MINN. DAILY, } \\
\text { Apr. 16, } 1998 \text { available at } \\
\text { http://www.mndaily.com/daily/1998/04/ } \\
\text { 16/news/ap416e.ap/. }\end{array}$ \\
\hline $\begin{array}{l}17 \text { Apr. } \\
1998\end{array}$ & New York Times & & $\begin{array}{l}\text { Amy Harmon, Racial Divide Found on } \\
\text { Information Highway, N.Y. TIMES, Apr. } \\
17,1998 \text {. }\end{array}$ \\
\hline $\begin{array}{l}18 \text { Apr. } \\
1998\end{array}$ & Financial Times & & $\begin{array}{l}\text { Louise Kehoe, High Streets in } \\
\text { Hyperspace, FIN. TIMES, Apr. 18, 1998, } \\
\text { at } 6 .\end{array}$ \\
\hline
\end{tabular}




\begin{tabular}{|c|c|c|c|}
\hline DATE & $\begin{array}{l}\text { PARTY MAKING } \\
\text { CLAIM }\end{array}$ & NOTES & SOURCE \\
\hline $\begin{array}{l}20 \mathrm{Apr} \\
1998\end{array}$ & $\begin{array}{l}\text { Ed.Net Briefs } \\
\text { (Education News and } \\
\text { Resources) }\end{array}$ & $\begin{array}{l}\text { A free weekly online } \\
\text { education newsletter. }\end{array}$ & $\begin{array}{l}\text { Ed.Net Briefs, April 20, 1998, available } \\
a t \text { http://www.edbriefs.com/usa97- } \\
98 / \text { usa04.20.98.html (citing Elizabeth } \\
\text { Wcise, Net Use Doubling Every 100 } \\
\text { Days, USA TODAY, Apr. 16, 1998). }\end{array}$ \\
\hline $\begin{array}{l}21 \mathrm{Apr} \\
1998\end{array}$ & $B B C$ News & & $\begin{array}{l}\text { Microsoft Challenges Browser Ruling, } \\
\text { BBC NEwS, Apr. } 21,1998, \text { available at } \\
\text { http://news.bbc.co.uk } / 1 / \mathrm{hi} / \mathrm{sci} / \text { tech } / 8156 \\
0 . \text { stm. }\end{array}$ \\
\hline $\begin{array}{l}30 \mathrm{Apr} \\
1998\end{array}$ & $\begin{array}{l}\text { U.S. Representative } \\
\text { Edward J. Markey (D- } \\
\text { MA) }\end{array}$ & $\begin{array}{l}\text { Remarks made in House } \\
\text { Subcommittee on } \\
\text { Telecommunications, } \\
\text { Trade, and Consumer } \\
\text { Protection Hearing on } \\
\text { Electronic Commerce, } \\
\text { April 30, } 1998 \text {. }\end{array}$ & $\begin{array}{l}\text { Hearing on Electronic Commerce } \\
\text { Before the House Subcomm. on } \\
\text { Telecommunications, Trade, and } \\
\text { Consumer Protection, 105th Cong. } \\
\text { (1998), available at } \\
\text { http://www.house.gov/markey/iss_telec } \\
\text { omm st } 980430 . h t m \text {. }\end{array}$ \\
\hline $\begin{array}{l}\text { I May } \\
1998\end{array}$ & $\begin{array}{l}\text { Commerce Secretary } \\
\text { William Daley }\end{array}$ & $\begin{array}{l}\text { Briefing on The } \\
\text { Emerging Digital } \\
\text { Economy. }\end{array}$ & $\begin{array}{l}\text { Will Rodgers, Digital Economy } \\
\text { Growing Fast, INTERNET TIMES, May 1, } \\
\text { 1998, at } \\
\text { http:/www.glreach.com/eng/ed/iv/it98/0 } \\
\text { 10598.html. }\end{array}$ \\
\hline $\begin{array}{l}5 \text { May } \\
1998\end{array}$ & Vice-President Al Gore & $\begin{array}{l}\text { Delivered at the } \\
\text { Economic Strategy } \\
\text { Institute. }\end{array}$ & $\begin{array}{l}\text { Al Gore, It's Technology, Stupid: } \\
\text { Shrinking the World and Building the } \\
\text { New Global Economy, in ECONOMIC } \\
\text { STRATEGY INSTITUTE STUDIES (1998). }\end{array}$ \\
\hline $\begin{array}{l}15 \text { May } \\
1998\end{array}$ & $\begin{array}{l}\text { Puget Sound Business } \\
\text { Journal }\end{array}$ & $\begin{array}{l}\text { Citing U.S. Commerce } \\
\text { Department in April. }\end{array}$ & $\begin{array}{l}\text { Let's Get Real about Online Advertising } \\
\text { Revenue, PUGET SOUND BuS. J., May } \\
\text { I5, 1998, available at } \\
\text { http://www.igorilla.com/gorilla/online_a } \\
\text { dv.html. }\end{array}$ \\
\hline $\begin{array}{l}25 \text { May } \\
1998\end{array}$ & $\begin{array}{l}\text { American Medical } \\
\text { News } \\
\text { (www.amednews.com) }\end{array}$ & & $\begin{array}{l}\text { Contemplating the Mysteries of } \\
\text { Bandwidth, AM. MED. NEwS, May } 25, \\
1998, \text { available at http://www.ama- } \\
\text { assn.org/sci- } \\
\text { pubs/amnews/net } 98 / n w k g 0525 . \mathrm{htm} \text {. }\end{array}$ \\
\hline $\begin{array}{l}\text { May } \\
1998\end{array}$ & Vice-President Al Gore & & $\begin{array}{l}\text { Al Gore, Connecting Communities for } \\
\text { the Future-Essay } 9 \text { (1998), available } \\
\text { at http://www.publicus.net/emfa- } \\
\text { event } 9805 / \mathrm{msg} \text { 00029.html. }\end{array}$ \\
\hline $\begin{array}{l}9 \text { Jun. } \\
1998\end{array}$ & $\begin{array}{l}\text { Business Times (South } \\
\text { Africa) }\end{array}$ & & $\begin{array}{l}\text { SA's Electronic Trade to Rocket, BuS. } \\
\text { TiMES (S. Afr.), Jun. 9, 1998, available } \\
\text { at } \\
\text { http://www.btimes.co.za/98/0906/survey } \\
\text { /survey02.htm. }\end{array}$ \\
\hline $\begin{array}{l}10 \mathrm{Jul} \\
1998\end{array}$ & $B B C$ News & & $\begin{array}{l}\text { Chris Nuttall, Inktomi Searches for Net } \\
\text { Profits in Europe, BBC NEwS, Jul. 10, } \\
1998 \text {, available at } \\
\text { http://news.bbc.co.uk/1/hi/business/the_ } \\
\text { company file/128974.stm. }\end{array}$ \\
\hline
\end{tabular}


The Failure of Good Intentions

\begin{tabular}{|c|c|c|c|}
\hline DATE & $\begin{array}{l}\text { PARTY MAKING } \\
\text { CLAIM }\end{array}$ & NOTES & SOURCE \\
\hline $\begin{array}{l}16 \text { Jul. } \\
1998\end{array}$ & $\begin{array}{l}\text { K. C. Kwong, Secretary } \\
\text { for Information } \\
\text { Technology and } \\
\text { Broadcasting (Hong } \\
\text { Kong) }\end{array}$ & & $\begin{array}{l}\text { K.C. Kwong, Internet and Its Use in } \\
\text { Electronic Commerce, Remarks at the } \\
\text { Luncheon Mceting of Century } 21 \text { Club } \\
\text { (Jul. 16, 1998), available at } \\
\text { http://www.info.gov.hk/itbb/cnglish/spe } \\
\text { ech/pr160798.htm. }\end{array}$ \\
\hline $\begin{array}{l}29 \text { Jul. } \\
1998\end{array}$ & $\begin{array}{l}\text { Senator Richard Alston } \\
\text { (Australian Minister of } \\
\text { Communications, } \\
\text { lnformation, } \\
\text { Technology and the } \\
\text { Arts) }\end{array}$ & Media Release & $\begin{array}{l}\text { Press Release, Australian Department of } \\
\text { Communications, Information, } \\
\text { Technology and the Arts, Towards an } \\
\text { Australian Strategy for The Information } \\
\text { Economy (Jul. } 29,1998 \text { ) available at } \\
\text { http://www.dcita.gov.au/Article/0,0_1- } \\
\text { 2 15-4_13173,00.html. }\end{array}$ \\
\hline $\begin{array}{l}15 \text { Aug. } \\
1998\end{array}$ & $\begin{array}{l}\text { ClO Enterprise } \\
\text { Magazine }\end{array}$ & & $\begin{array}{l}\text { Digital Economics, CIO ENTERPRISE } \\
\text { MAG., Aug. 15, 1998, available at } \\
\text { http://www.cio.com/archive/enterprise/0 } \\
81598 \text { plugged content.html. }\end{array}$ \\
\hline $\begin{array}{l}\text { Nov } \\
1998\end{array}$ & $\begin{array}{l}\text { Journal of Internet } \\
\text { Banking and Commerce }\end{array}$ & & $\begin{array}{l}\text { Jackie Cuevas, The Internet Banking } \\
\text { Horizon: Bleak or Bright for } \\
\text { Community Banks?, J. INTERNET } \\
\text { BANKING \& COM. (1998), available at } \\
\text { http://www.artaydev.com/commerce/JI } \\
\text { BC/981l-14.htm. }\end{array}$ \\
\hline $\begin{array}{l}6 \text { Dec. } \\
1998\end{array}$ & Reuters & Study. & $\begin{array}{l}\text { Francis Hong, Internet Capacity Major } \\
\text { Theme For 1999, REUTERS NEwS } \\
\text { SERV., Dec. 6, 1998, available at } \\
\text { http://www.xent.com/FoRK- } \\
\text { archive/nov98/0099.html. }\end{array}$ \\
\hline $\begin{array}{l}10 \mathrm{Dec} . \\
1998\end{array}$ & $\mathrm{CNN}$ & & $\begin{array}{l}\text { Kathleen Ohison, Study Sees Bandwidth } \\
\text { Crunch in '99, CNN.COM, Dec. } 10, \\
1998, a t \\
\text { http://www.cnn.com/TECH/computing/ } \\
9812 / 10 / \text { bandwidth.jdg/. }\end{array}$ \\
\hline$\overline{1998}$ & $\begin{array}{l}\text { John Sidgmore (then } \\
\text { CEO of WorldCom) }\end{array}$ & & $\begin{array}{l}\text { Yochi J. Dreazen, Wildly Optimistic } \\
\text { Data Drove Telecoms To Build Fiber } \\
\text { Glut, WALL ST. J. ONLINE, Sept. 26, } \\
\text { 2002, available at } \\
\text { http://online.wsj.com/article_print/0,SB } \\
\text { 1032982764442483713,00.html. }\end{array}$ \\
\hline 1998 & Foresight & & $\begin{array}{l}\text { Internet Traffic Exploding, FORESIGHT } \\
\text { (1998), available at } \\
\text { http://www.kltprc.net/emergingissues/C } \\
\text { hpt } 59 . \mathrm{htm} \text {. }\end{array}$ \\
\hline$\overline{1998}$ & $\begin{array}{l}\text { South Australian Police, } \\
\text { Commercial and } \\
\text { Electronic Crime } \\
\text { Branch }\end{array}$ & & $\begin{array}{l}\text { COMMERCIAL \& ELECTRONIC CRIME } \\
\text { BRANCH, SOUTH AUSTRALIAN POLICE, } \\
\text { COMPUTER CRIME, at } \\
\text { http://www.sapolice.sa.gov.au/crime/fra } \\
\text { ud/ftfcomp.htm. }\end{array}$ \\
\hline$\overline{1998}$ & Lucent Technologies & Annual Report, 1998 & $\begin{array}{l}\text { LUCENT TECHNOLOGIES, INC., } 1998 \\
\text { ANNUAL REPORT (May 17, 1999), } \\
\text { available at } \\
\text { http://www.lucent.com/investor/annual/ } \\
\text { 98/pdf download.html. }\end{array}$ \\
\hline
\end{tabular}




\begin{tabular}{lll}
\hline DATE & $\begin{array}{l}\text { PARTY MAKING } \\
\text { CLAIM }\end{array}$ & NOTES \\
\hline $\begin{array}{l}\text { 9Feb. } \\
1999\end{array}$ & ABCNews.Com & \\
& & \\
\hline 5 Mar. & Collaborative Research & $\begin{array}{l}\text { Collaborative Research } \\
\text { press release. }\end{array}$
\end{tabular}

SOURCE

Erin Arvedlund, Snip the Wires, Stay in Touch, ABCNEWS.COM, Feb. 9, 1999, available at

http://abcnews.go.com/sections/business /DailyNews/wireless990209.html. Press Release, Collaborative Research: Internet Traffic Still Growing, Snafus Still Occurring, But Report Details Why So Much Actually Works, PR NEwSWIRE, Mar. 3, 1999.

15 Mar. Wireless Review
Rhonda Wickham, Putting the Zip in IP, 1999 WIRELESS REV., Mar. 15, 1999 available at http://www.wirelessreview.com/ar/wirel ess_putting zip ip/.

29 Mar. Tellabs Operations, Inc. $\quad$ Press Relcase

Press Release, Tellabs, Tellabs 1999 Introduces TITAN $B$ 4500GS Global Services Delivery System, Mar. 29, 1999, available at http://www.tellabs.com/news/99news/nr 032999.shtml.

$26 \mathrm{Apr}$ Lucent Technologies Press Releasc

Press Release, Lucent Technologies, Lucent Delivers New Network Solution to Alleviate Internet Traffic Jams: IPWorXTM Speeds Downloads, Frees Network Bandwidth and Supports New Applications, Apr. 26, 1999, available $a t$

http://www.lucent.com/press/0499/9904 26.coe.html.

\begin{tabular}{ll}
\hline Apr. & Pratt Telecommunity \\
1999 & Center, Inc.
\end{tabular}
Pratt Telecommunity Center, Inc., When Technology Meets Desire Something Powerful Happens, Apr. 1999, available at

http:/www.futurekansas.com/ptc/edfeat. htm.

\begin{tabular}{|c|c|c|c|}
\hline $\begin{array}{l}\text { Apr. } \\
1999\end{array}$ & Wired Magazine & & $\begin{array}{l}\text { Jeffrey S. Young, The Next Net, WIRED } \\
\text { MAG., Apr. 1999, available at } \\
\text { http://www.wired.com/wired/archive/7. } \\
\text { 04/cisco.html. }\end{array}$ \\
\hline $\begin{array}{l}\text { Apr. } \\
1999\end{array}$ & $\begin{array}{l}\text { Exchange Magazine for } \\
\text { Business }\end{array}$ & $\begin{array}{l}\text { Article containing the } \\
\text { "100 days" statement } \\
\text { posted on } \\
\text { PricewaterhouseCoopers' } \\
\text { (Canada) Website. }\end{array}$ & $\begin{array}{l}\text { Dennis Grimm, The } \\
\text { Telecommunications Revolution, } \\
\text { ExCHANGE MAG. BUS., Apr. 1999, } \\
\text { available at } \\
\text { http://www.pwcglobal.com/extweb/man } \\
\text { issue.nsf/DocID/953E8C08680CA1B48 } \\
\text { 52567C3007C80FC. }\end{array}$ \\
\hline $\begin{array}{l}12 \text { Jul. } \\
1999\end{array}$ & $\begin{array}{l}\text { Houston Business } \\
\text { Journal }\end{array}$ & & $\begin{array}{l}\text { Monica Perin, "Virtual Customer } \\
\text { Intimacy" Is Goal of Internet Banking, } \\
\text { Houston BuS. J., Jul. } 9,1999 \text {, } \\
\text { available at } \\
\text { http://houston.bizjoumals.com/houston/ } \\
\text { stories/1999/07/12/focus } 2 . \mathrm{html} \text {. }\end{array}$ \\
\hline
\end{tabular}


The Failure of Good Intentions

\begin{tabular}{|c|c|c|c|}
\hline DATE & $\begin{array}{l}\text { PARTY MAKING } \\
\text { CLAIM }\end{array}$ & NOTES & SOURCE \\
\hline $\begin{array}{l}12 \text { Jul. } \\
1999\end{array}$ & $\begin{array}{l}\text { Broadband Publishing } \\
\text { Corp. }\end{array}$ & $\begin{array}{l}\text { Special Advertising } \\
\text { Section entitled Building } \\
\text { Broadband Networks. }\end{array}$ & $\begin{array}{l}\text { John M. McQuillan, Technology } \\
\text { Analysis: What's Next for The Net?, } \\
\text { advertisement in BUS. WK., July 12, } \\
1999 .\end{array}$ \\
\hline $\begin{array}{l}15 \text { Oct } \\
1999\end{array}$ & $\begin{array}{l}\text { Gloria Tristani, FCC } \\
\text { Commissioner }\end{array}$ & & $\begin{array}{l}\text { Gloria Tristani, Remarks at the } \\
\text { International Business Conterence, St. } \\
\text { Croix, U.S.V.J. (Oct. 15, 1999), } \\
\text { available at } \\
\text { http://www.fcc.gov/Speeches/Tristani/s } \\
\text { pgt917.html. }\end{array}$ \\
\hline $\begin{array}{l}6 \text { Dec. } \\
1999\end{array}$ & Financial Times & & $\begin{array}{l}\text { Eroding Boundaries of Time and Space, } \\
\text { FIN. TIMES, Dec. 6, 1999, available at } \\
\mathrm{http}: / / \mathrm{specials.ft.com} / \mathrm{h} / \mathrm{specials} / \mathrm{sp} 4086 \text {. } \\
\mathrm{htm} \text {. }\end{array}$ \\
\hline $\begin{array}{l}27 \text { Jan. } \\
2000\end{array}$ & $\begin{array}{l}\text { William E. Kennard, } \\
\text { Chairman of the Federal } \\
\text { Communications } \\
\text { Commission }\end{array}$ & & $\begin{array}{l}\text { Press Release, Federal Communications } \\
\text { Commission, Chairman Kennard Tells } \\
\text { Portuguese Telecom Industry that } \\
\text { Continued Growth of Internet Depends } \\
\text { on True and Full Competition in } \\
\text { Telecom Marketplace (Jan. } 7,2000 \text { ), } \\
\text { available at } \\
\text { http://www.fcc.gov/Speeches } / \text { Kennard/ } \\
\text { Statements } / 2000 / \text { stwek011.html. }\end{array}$ \\
\hline $\begin{array}{l}24 \text { Jan. } \\
2000\end{array}$ & $\begin{array}{l}\text { Chris Riegel, Chief } \\
\text { Technical Officer, OCD } \\
\text { Network Systems }\end{array}$ & Announcement & $\begin{array}{l}\text { Press Release, Novell, OCD Network } \\
\text { Systems Debuts Family of High- } \\
\text { Performance Network Caching Products } \\
\text { (Jan. } 24,2000 \text { ), available at } \\
\text { http://www.novell.com/news/press/press } \\
\text { room/partner/archive/2000/0l/pr00007. } \\
\text { html. }\end{array}$ \\
\hline $\begin{array}{l}7 \text { Feb. } \\
2000\end{array}$ & Lucent Technologies & $\begin{array}{l}\text { 3GPP Workshop } \\
\text { (PowerPoint } \\
\text { presentation) }\end{array}$ & $\begin{array}{l}\text { Willem Koelewijn, Lucent } \\
\text { Tcchnologics, Next Generation } \\
\text { Wireless: Business Drivers for an All-IP } \\
\text { Network, Presentation at the 3GPP } \\
\text { Workshop in Nice (Feb. 2000), } \\
\text { available at } \\
\text { http://www.3gpp.org/ftp/workshop/Arch } \\
\text { ive/0002IP/Docs/PDF/AlP-000007.pdf. }\end{array}$ \\
\hline $\begin{array}{l}23 \mathrm{Feb} \\
2000\end{array}$ & Washington Times & & $\begin{array}{l}\text { Kenneth Brown, Breaking Windows } \\
\text { over Antitrust Dogma, WASH. TiMES, } \\
\text { Feb. } 23,2000 \text {, at } 13 \text {. }\end{array}$ \\
\hline $\begin{array}{l}13 \text { Mar. } \\
2000\end{array}$ & New York Times & & $\begin{array}{l}\text { Stephen Labaton, F.C.C. to Promole a } \\
\text { Trading System To Sell Airwaves, N.Y. } \\
\text { TIMES, Mar. 13, 2000, at 1, available at } \\
\text { http://query.nytimes.com/search/article- } \\
\text { page.html?res=9B02E2DE133BF930A2 } \\
\text { 5750C0A9669C8B63. }\end{array}$ \\
\hline $\begin{array}{l}14 \text { Mar. } \\
2000\end{array}$ & $\begin{array}{l}\text { William E. Kennard, } \\
\text { Chairman of the Federal } \\
\text { Communications } \\
\text { Commission }\end{array}$ & & $\begin{array}{l}\text { Chairman William E. Kennard, } \\
\text { Connecting the Globe: The Latin } \\
\text { America Initiative, Address at Lima, } \\
\text { Peru (Mar.14, 2000). }\end{array}$ \\
\hline
\end{tabular}




\begin{tabular}{|c|c|c|c|}
\hline DATE & $\begin{array}{l}\text { PARTY MAKING } \\
\text { CLAIM }\end{array}$ & NOTES & SOURCE \\
\hline $\begin{array}{l}12 \mathrm{Jul} \\
2000\end{array}$ & $\begin{array}{l}\text { David Payne, Head of } \\
\text { the Optoelectronics } \\
\text { Research Center at the } \\
\text { University of } \\
\text { Southampton in the } \\
\text { U.K. (and one of the } \\
\text { inventors of the Erbium } \\
\text { Doped Fiber Amplifier) }\end{array}$ & $\begin{array}{l}\text { Light Reading-Global } \\
\text { Site for Optical } \\
\text { Networking. }\end{array}$ & $\begin{array}{l}\text { David Payne, Bandwidth Bonanza } \\
\text { "Won't Happen," LIGHT READING, Jul. } \\
\text { 12,2000, available at } \\
\text { http://www.lightreading.com/document. } \\
\text { asp?doc_id=1142. }\end{array}$ \\
\hline $\begin{array}{l}31 \mathrm{Jul} \\
2000\end{array}$ & Luxcore & Press Release. & $\begin{array}{l}\text { Press Release, LuxCore, Luxcore } \\
\text { Secures } \$ 10 \text { Million in First-Round } \\
\text { Funding (Jul. 31, 2000), available at } \\
\text { http://www.luxcore.com/ne_pressroom_ } \\
\text { july2000.html. }\end{array}$ \\
\hline $\begin{array}{l}24 \text { Aug. } \\
2000\end{array}$ & David Williams & $\begin{array}{l}\text { Partner at Draper Fisher } \\
\text { Jurvetson, a Silicon } \\
\text { Valley investment firm. }\end{array}$ & $\begin{array}{l}\text { Press Release, Surfgold.com, Surfing } \\
\text { For Gold: Success by Supporting Others } \\
\text { (Aug. 24, 2000), available at } \\
\text { http://www.surfgold.com/Corporate/ne } \\
\text { wsroom/media b24aug.asp. }\end{array}$ \\
\hline $\begin{array}{l}\text { Aug. } \\
2000\end{array}$ & IndustryWeek.Com & & $\begin{array}{l}\text { Lance Secretan, Spirit at Work- } \\
\text { Learning Fuels the Soul, } \\
\text { INDUSTRYWEEK.COM, Aug. 21, 2000, } \\
\text { available at } \\
\text { http://www.industryweek.com/Columns } \\
\text { /ASP/columns.asp?Columnld=650. }\end{array}$ \\
\hline $\begin{array}{l}\text { Sept. } \\
2000\end{array}$ & $\begin{array}{l}\text { UUNet Chief Operating } \\
\text { Officer, Kevin Boyne }\end{array}$ & $\begin{array}{l}\text { Told the Washington } \\
\text { Post: "Over the past five } \\
\text { years, Internet usage has } \\
\text { doubled every three } \\
\text { months. We're seeing an } \\
\text { industry that's exploding } \\
\text { at exponential rates." }\end{array}$ & $\begin{array}{l}\text { Peter Behr, On or Off the Bandwidth } \\
\text { Bandwagon?, WASH. POST, Sept. } 24 \text {, } \\
2000 \text {, at Hl. }\end{array}$ \\
\hline $\begin{array}{l}9 \text { Oct. } \\
2000\end{array}$ & Business Week & & $\begin{array}{l}\text { John G. Shinal \& Timothy J. Mullaney, } \\
\text { At the Speed of Lighlt, BuS. WK., Oct. 9, } \\
2000 \text {, at } 144 \text {, available at } \\
\text { http://www.businessweek.com } / 2000 / 00 \\
41 / \mathrm{b} 3702185 . \mathrm{htm} \text {. }\end{array}$ \\
\hline $\begin{array}{l}18 \text { Oct. } \\
2000\end{array}$ & $\begin{array}{l}\text { Stephen Butler, CEO of } \\
\text { PowerTel }\end{array}$ & Press Release & $\begin{array}{l}\text { Press Release, PowerTel, Saise } \\
\text { Telecommunications Selects } \\
\text { PowerTel's High Speed Delivery } \\
\text { Platform (Oct. } 18,2000 \text { ). }\end{array}$ \\
\hline $\begin{array}{l}19 \mathrm{Dec} . \\
2000\end{array}$ & Red Herring & & $\begin{array}{l}\text { Ron Recinto, How a Real Estate } \\
\text { Company Turned Telecom, RED } \\
\text { HERRING, Dec. } 19,2000 \text {, at } 72 \text {, } \\
\text { available at } \\
\text { http://www.redherring.com/industries/2 } \\
000 / 1219 / \text { ind-mag-88- } \\
\text { americas } 121900 . h t m l .\end{array}$ \\
\hline $\begin{array}{l}\text { Dec. } \\
2000\end{array}$ & $\begin{array}{l}\text { Economic Development } \\
\text { Digest }\end{array}$ & & $\begin{array}{l}\text { Aliceann Wohlbruck \& Melissa Levy, } \\
\text { Bridging the Digital Divide, EcoN. } \\
\text { DEV. DIG., Dec. 2000, available at } \\
\text { http://www.nado.org/pubs/decl.html. }\end{array}$ \\
\hline 2000 & $\begin{array}{l}\text { Reed Hundt, Chairman } \\
\text { of FCC from } 1993 \text { to } \\
1997\end{array}$ & $\begin{array}{l}\text { Hundt wrote that "[i]n } \\
1999, \text { data traffic was } \\
\text { doubling every } 90 \text { days." }\end{array}$ & $\begin{array}{l}\text { REED E. HUNDT, YOU SAY YOU WANT } \\
\text { A REVOLUTION: A STORY OF } \\
\text { INFORMATION AGE POLITICS }(2000) \text {. }\end{array}$ \\
\hline
\end{tabular}


The Failure of Good Intentions

\begin{tabular}{|c|c|c|c|}
\hline DATE & $\begin{array}{l}\text { PARTY MAKING } \\
\text { CLAIM }\end{array}$ & NOTES & SOURCE \\
\hline 2000 & Information \& Security & & $\begin{array}{l}\text { Dialectics of Information Security, } 4 \\
\text { INFO. \& SECURITY (2000), available at } \\
\text { http://www.isn.ethz.ch/researchpub/publ } \\
\text { ihouse/infosecurity/volume_4/Editorial. } \\
\text { htm. }\end{array}$ \\
\hline $\begin{array}{l}3 \mathrm{Apr} \\
2001\end{array}$ & $\begin{array}{l}\text { Mike Pence, Chairman, } \\
\text { House Committee on } \\
\text { Small Busincss; } \\
\text { Subcommittee on } \\
\text { Regulatory Reform \& } \\
\text { Oversight }\end{array}$ & & $\begin{array}{l}\text { Promoting Internet Entrepreneurship: } \\
\text { Should The Government Take Any } \\
\text { Action?: Before the Subcomm. on } \\
\text { Regulatory Reform \& Oversight, House } \\
\text { Comm. on Small Business, } 107 \text { th Cong. } \\
\text { (2001), available at } \\
\text { http://www.house.gov/smbiz/hearings/1 } \\
07 \text { th/2001/010403/pence.html } \\
\text { (statement of Mike Pence, Chairman, } \\
\text { House Subcomm, on Regulatory } \\
\text { Reform \& Oversight). }\end{array}$ \\
\hline $\begin{array}{l}30 \mathrm{Jul} \\
2001\end{array}$ & $\begin{array}{l}\text { Mississippi Business } \\
\text { Journal }\end{array}$ & & $\begin{array}{l}\text { Lymne Wilbanks Jeter, Small Towns } \\
\text { Anticipate High-Speed Internet Access, } \\
23 \text { MISS. BUS. J. ONLINE, Jul.-Aug. } \\
2001, \text { available at } \\
\text { http://student.bus.olemiss.edu/lparchma } \\
\text { n/Research/small-bus.pdf. }\end{array}$ \\
\hline $\begin{array}{l}29 \mathrm{Oct} . \\
2001\end{array}$ & InfoSat & & $\begin{array}{l}\text { Network Overload: Problems and } \\
\text { Solutions, INFOSAT, Oct. 29, 2001. }\end{array}$ \\
\hline 2001 & $\begin{array}{l}\text { Connect-World (Annual } \\
\text { Issue) }\end{array}$ & & $\begin{array}{l}\text { Patrick Omutia, Emerging } \\
\text { Communication Technologies - } \\
\text { Opportunities for Africa, } \\
\text { CONNECTWORLD (2001), available at } \\
\text { http://www.connect- } \\
\text { world.com/past_issues/africa/2001/annu } \\
\text { a!_issue/p_omutia_2001.asp. }\end{array}$ \\
\hline 2002 & Intel & Intel product description. & $\begin{array}{l}\text { OEM Internet Solutions, available at } \\
\text { http://www.intel.com/network/csp/prod } \\
\text { ucts/internet/. }\end{array}$ \\
\hline $\begin{array}{l}15 \text { Jan. } \\
2003\end{array}$ & $\begin{array}{l}\text { Government Computer } \\
\text { News }\end{array}$ & & $\begin{array}{l}\text { Blast through the Bottlenecks: } \\
\text { Enhancing the End-User Experience } \\
\text { with Content Delivery Networks, Gov'T } \\
\text { COMPUTER NEwS, Jan. 22, 2003, } \\
\text { available at } \\
\text { http://www.gen.com/Cisco/cdnreport.pd } \\
\text { f. }\end{array}$ \\
\hline Unknown & Sprint & & $\begin{array}{l}\text { Sprint, Dedicated Internet Services, } \\
\text { available at } \\
\text { https://www.sprintbmo.com/bizpark/pag } \\
\text { e/segment/product_solutions/product_o } \\
\text { ptions.jsp?product_id=196. }\end{array}$ \\
\hline Unknown & Cisco & & $\begin{array}{l}\text { Cisco Systems, What is the Role of } \\
\text { Caching, available at } \\
\text { http://www.cisco.com/warp/public/732/ } \\
\text { abc/technologies/caching.shtml. }\end{array}$ \\
\hline
\end{tabular}


